\title{
Bioactivities and Health Benefits of Wild Fruits
}

\author{
$\mathrm{Ya} \mathrm{Li}^{1}{ }^{1}$, Jiao-Jiao Zhang ${ }^{1}$, Dong-Ping $\mathrm{Xu}^{1}{ }^{1}$, Tong Zhou ${ }^{1}$, Yue Zhou ${ }^{1}$, Sha $\mathrm{Li}^{2}$ and Hua-Bin $\mathrm{Li}{ }^{1,3, *}$ \\ 1 Guangdong Provincial Key Laboratory of Food, Nutrition and Health, School of Public Health, Sun Yat-Sen \\ University, Guangzhou 510080, China; liya28@mail2.sysu.edu.cn (Y.L.); zhangjj46@mail2.sysu.edu.cn (J.-J.Z.); \\ xudp@mail2.sysu.edu.cn (D.-P.X.); zhout43@mail2.sysu.edu.cn (T.Z.); zhouyue3@mail2.sysu.edu.cn (Y.Z.) \\ 2 School of Chinese Medicine, The University of Hong Kong, Hong Kong, China; u3003781@connect.hku.hk \\ 3 South China Sea Bioresource Exploitation and Utilization Collaborative Innovation Center, \\ Sun Yat-Sen University, Guangzhou 510006, China \\ * Correspondence: lihuabin@mail.sysu.edu.cn; Tel.: +86-20-873-323-91
}

Academic Editor: Maurizio Battino

Received: 24 May 2016; Accepted: 28 July 2016; Published: 4 August 2016

\begin{abstract}
Wild fruits are exotic or underutilized. Wild fruits contain many bioactive compounds, such as anthocyanins and flavonoids. Many studies have shown that wild fruits possess various bioactivities and health benefits, such as free radical scavenging, antioxidant, anti-inflammatory, antimicrobial, and anticancer activity. Therefore, wild fruits have the potential to be developed into functional foods or pharmaceuticals to prevent and treat several chronic diseases. In the present article, we review current knowledge about the bioactivities and health benefits of wild fruits, which is valuable for the exploitation and utilization of wild fruits.
\end{abstract}

Keywords: wild fruit; bioactivity; antioxidant; anticancer; anti-inflammatory

\section{Introduction}

Fruits and vegetables, containing abundant dietary fiber, vitamins, and minerals, in particular large amounts of phytochemicals [1-7], are recommended by nutritionists because of their health benefits $[8,9]$. Phytochemicals in these natural products are considered to be responsible for positive health outcomes. Particularly, it is widely noted that plants produce a great deal of antioxidants to combat the oxidative stress induced by oxygen and light in the natural environment [10]. Oxidative stress performs an essential role in multiple chronic diseases [11-13]. Therefore, antioxidants in fruit and vegetables have been extensively explored for their effects on several diseases. Epidemiological and nutritional studies suggested that the higher one's fruit and vegetable consumption, the lower the incidence of chronic diseases such as coronary heart problems, cancer, and Alzheimer's disease [14,15].

Wild fruits are fruits of wild plants, and are often exotic, underutilized, or less known. Many wild fruits are safe to consume, and some have been developed as medicines. Due to different genotypes and environmental concerns, wild fruits contain rich phytochemicals such as anthocyanin and flavonoids. Therefore, wild fruits are often considered to be healthy foods. In recent years, wild fruits have attracted increasing attention, and accumulative investigations have been performed for their bioactive effects, such as antioxidant, antimicrobial anti-inflammatory, and anticancer effects. These studies pointed out that wild fruits could have the potential to prevent and treat some chronic diseases. This review summarizes the bioactivities and health benefits of wild fruits.

\section{Bioactivities of Wild Fruits}

\subsection{Antioxidant Activity}

Free radicals are normally produced as a byproduct of cellular metabolism. Free radicals are capable of killing bacteria, damaging biomolecules, provoking immune responses, activating 
oncogenes, causing atherogenesis, and enhancing the ageing process [16]. The most important classes of radical species generated in living systems are reactive oxygen and nitrogen species (ROS and RNS). The excessive production of ROS and RNS could play a pivotal part in many human chronic diseases, including atherosclerosis, diabetes mellitus, cancer, rheumatoid arthritis, cataract, and Parkinson's disease [17]. Various natural products have been proved to have antioxidant activities, such as fruits, vegetables, edible flowers, cereal grains, wine, herbal plants, and their tea infusions [18-26]. Therefore, natural resources of antioxidants have been considered as quite important. There have been several experiments both in vivo and in vitro proving that many wild fruits possess antioxidant activities, such as wild blueberries, wild apples, and wild hawthorn fruits.

\subsubsection{In Vitro Studies}

Several studies have evaluated the antioxidant capacity of a certain species of wild fruit. The underutilized wild berry fruit Prunus mahaleb showed strong antioxidant activity [27]. The results of oxygen radical absorption capacity (ORAC) and 2,2'-azinobis-3-ethylbenzothiazoline-6-sulphonate (ABTS. ${ }^{+}$, expressed as trolox equivalent antioxidant capacity (TEAC) value) assays were 150 and $45 \mathrm{mmol}$ Trolox equivalents $/ \mathrm{kg}$ fresh weight, respectively. Furthermore, the P. mahaleb fruit had high anthocyanin content, which was comparable to that of some reported superfruits (bilberries and blackcurrants). Moreover, Araca-pera (Psidium acutangulum), an exotic guava fruit from the Amazon, was analyzed for antioxidant properties by 2,2-diphenyl-1-picrylhydrazyl (DPPH) free radical, ABTS free radical scavenging capacity $(24.96 \pm 0.75,90.57 \pm 0.63 \mathrm{mg}$ of vitamin C/100 $\mathrm{g}$ fresh fruit, respectively), and cell-based assays ( $76 \%-100 \%)$ [28]. Results indicated that this guava fruit could be developed into functional foods for the prevention of chronic diseases due to its antioxidant activity. In another study, the antioxidant activities of water, ethyl acetate, acetone, and methanol extracts from the wild Sorbus torminalis fruit were assessed by DPPH, ABTS, superoxide anion radicals scavenging, and ferric reducing antioxidant power (FRAP) assays. The antioxidant activity and total phenolic concentration were both ranked as water $>$ ethyl acetate $>$ acetone $>$ methanol extracts [29]. Another edible wild fruit, Ziziphus mistol, was analyzed for its antioxidant activity. All extracts showed strong antioxidant activity. As a hydrogen or electron donor, the ethanol extract (EME) was significantly more effective than the aqueous one (AME); when scavenging hydroxyl and superoxide radicals, AME was significantly more effective than EME. In addition, a dose-dependent relationship $\left(R^{2}>0.90\right)$ was found between polyphenols content and antioxidant capacity. These results suggested that consumption of Ziziphus mistol fruit could be encouraged due to its antioxidant activity [30]. The pulp of wild cherimoya fruits (Annona cherimola) was also assessed for the antioxidant capacities of its methanol, ethanol, and dimethyl formamide extracts. The three extracts all showed strong free radical capturing and antioxidant activities. Among them, the dimethyl formamide extract showed the highest DPPH and ABTS scavenging and FRAP activities, and the ethanol extract showed the strongest anti-lipid peroxidation activity [31]. In another study, a crude extract of Myrica esculenta fruit was assessed for antioxidant properties. Results showed that the extracts exhibited considerable antioxidant potential based on data from DPPH, ABTS, and FRAP assays. Moreover, the antioxidant capacity was positively correlated with total phenolic and total flavonoids contents [32]. The wild bilberry (Vaccinium meridionale) is an edible fruit from Colombia. Garzon et al. evaluated its antioxidant activity and the results of ABTS and FRAP assays proved its strong antioxidant activity [33]. In another study, the antioxidant activity of fruit from wild Lycium ruthenicum, a nutritional food that has been used in traditional Chinese medicine, was evaluated. The methanol extracts exhibited high antioxidant activity in ABTS, DPPH, and FRAP assays [34]. In addition, hydrophilic extracts of wild acerola (Malpighia emarginata) pulps and juices were analyzed for antioxidant activities. Results of DPPH, ABTS, and FRAP assays indicated that the antioxidant activity of acerola juice was stronger than that of the fruit juices reported in the literature, such as strawberry, grape, or apple. In addition, anthocyanins, flavonoids, and phenolic acids fractions were separated; among them, phenolic acids showed the highest antioxidant activity, indicating that phenolic acids contributed the most to the antioxidant 
property of wild acerola fruit [35]. Furthermore, Koca et al. analyzed the antioxidant activity of purple mulberry (Morus rubra) fruits growing wild in Turkey. FRAP assay was used and the average value was $33.90 \mu \mathrm{mol} / \mathrm{g}$ [36]. In addition, fruits of wild Bunium persicum, Elaeagnus latifolia, Solanum incanum, Rosa canina, Mespilus germanica, Aristotelia chilensis, Myrtus communis, Rubus hirsutus, Piper capense, Vitis coignetiae, Prunus spinosa, Syzygium cumini, and Vatis amurensis also showed strong antioxidant activities [37-49]; the related information is displayed in Table 1.

Table 1. Antioxidant activities of some wild fruits.

\begin{tabular}{|c|c|c|c|}
\hline Wild Fruits & Bioactive Compounds & Effects & References \\
\hline 56 wild fruits from South China & polyphenols & antioxidant activity & [3] \\
\hline Prunus mahaleb & total anthocyanin and phenolics & $\begin{array}{l}\text { scavenging free radicals } \\
\text { (oxygen radicals) }\end{array}$ & [27] \\
\hline Psidium acutangulum & $\begin{array}{l}\text { phenolics, citric, annurcoic, } \omega 3, \omega 6, \\
\omega 9 \text { fatty acids, and ascorbic acid }\end{array}$ & $\begin{array}{l}\text { scavenging free radicals } \\
\text { (DPPH, ABTS) }\end{array}$ & [28] \\
\hline Sorbus torminalis & phenolic compounds & $\begin{array}{l}\text { scavenging free radicals (ABTS, } \\
\text { superoxide anion radicals), } \\
\text { antioxidant activity }\end{array}$ & [29] \\
\hline Ziziphus mistol & polyphenols & $\begin{array}{l}\text { scavenging free radicals (ABTS, } \\
\text { DPPH, superoxide and } \\
\text { hydroxyl radicals) }\end{array}$ & [30] \\
\hline Annona cherimola & not mentioned & $\begin{array}{l}\text { scavenging free radicals (DPPH, } \\
\text { ABTS), antioxidant activity, } \\
\text { inhibition of lipid peroxidation }\end{array}$ & [31] \\
\hline Myrica esculenta & polyphenols & $\begin{array}{l}\text { scavenging free radicals (DPPH, } \\
\text { ABTS), antioxidant activity }\end{array}$ & [32] \\
\hline Vaccinium meridionale & phenolic compounds & $\begin{array}{l}\text { scavenging free radicals (ABTS), } \\
\text { antioxidant activity }\end{array}$ & [33] \\
\hline Lycium ruthenicum & polyphenols & $\begin{array}{l}\text { scavenging free radicals (DPPH, } \\
\text { ABTS), antioxidant activity }\end{array}$ & [34] \\
\hline Malpighia ernarginata & phenolic acids & $\begin{array}{l}\text { scavenging free radicals (DPPH, } \\
\text { ABTS, oxygen radical) }\end{array}$ & [35] \\
\hline Morus rubra & not mentioned & antioxidant activity & [36] \\
\hline Bunium persicum & Phenolics and flavonoids & $\begin{array}{l}\text { scavenging free radicals (DPPH), } \\
\text { antioxidant activity }\end{array}$ & [37] \\
\hline Elaeagnus latifolia & phenolics and flavonoids & $\begin{array}{l}\text { scavenging hydroxyl radicals, } \\
\text { superoxide radicals, singlet oxygen } \\
\text { radicals, hypochlorous acid }\end{array}$ & [38] \\
\hline Solanum incanum & $\begin{array}{l}\text { 3-O-acetyl-and4-O-acetyl-5-O- } \\
(E) \text {-caffeoylquinic acids }\end{array}$ & $\begin{array}{l}\text { scavenging free radicals (ABTS, } \\
\text { DPPH) and iron chelation activity }\end{array}$ & [39] \\
\hline Rosa canina & $\begin{array}{l}\alpha \text {-tocopherol, } \beta \text {-carotene, reducing } \\
\text { sugar, and ascorbic acid }\end{array}$ & $\begin{array}{l}\text { scavenging free radicals (DPPH), } \\
\text { reducing power, inhibition of } \\
\beta \text {-carotene bleaching and lipid } \\
\text { peroxidation }\end{array}$ & [40] \\
\hline Mespilus germanica & not mentioned & $\begin{array}{l}\text { scavenging nitric oxide and } \mathrm{H}_{2} \mathrm{O}_{2} \\
\text { radicals, inhibition of } \\
\text { lipid peroxidation }\end{array}$ & [41] \\
\hline Aristotelia chilensis & phenolics & $\begin{array}{l}\text { scavenging free radicals (DPPH, } \\
\text { superoxide radicals, oxygen } \\
\text { radicals), antioxidant activity, } \\
\text { inhibition of lipid peroxidation }\end{array}$ & [42] \\
\hline Myrtus communis & not mentioned & $\begin{array}{l}\text { scavenging free radicals (DPPH, } \\
\beta \text {-carotene-linoleic acid) }\end{array}$ & [43] \\
\hline Rubus hirsutus & Phenolics and flavonoids & $\begin{array}{l}\text { scavenging free radicals (DPPH), } \\
\text { antioxidant activity }\end{array}$ & [44] \\
\hline Piper capense & not mentioned & scavenging free radicals (ABTS) & [45] \\
\hline Vitis coignetiae & anthocyanins & $\begin{array}{l}\text { scavenging free radicals } \\
\text { (ABTS, DPPH) }\end{array}$ & [46] \\
\hline
\end{tabular}


Table 1. Cont.

\begin{tabular}{|c|c|c|c|}
\hline Wild Fruits & Bioactive Compounds & Effects & References \\
\hline Syzygium cumini & $\begin{array}{l}\text { phenolics, tannins, } \\
\text { and anthocyanins }\end{array}$ & $\begin{array}{l}\text { scavenging free radicals (DPPH, } \\
\text { hydroxyl radical and superoxide } \\
\text { radical), inhibition of } \\
\text { lipid peroxidation }\end{array}$ & [48] \\
\hline Vatis amurensis & $\begin{array}{l}\text { catechin, epicatechin, } \\
\text { 4-methyl-catechol, gallic, } \\
\text { protocatechuic, chlorogenic, caffeic, } \\
\text { p-coumaric, and syringic acids }\end{array}$ & scavenging superoxide radicals & [49] \\
\hline $\begin{array}{l}14 \text { wild genotypes of } \\
\text { Citrus reticulata }\end{array}$ & not mentioned & $\begin{array}{l}\text { scavenging free radicals (DPPH, } \\
\text { ABTS, oxygen radicals), } \\
\text { antioxidant activity }\end{array}$ & [50] \\
\hline 10 crabapples (Malus wild species) & polyphenols, flavonoids & $\begin{array}{l}\text { scavenging free radicals (DPPH, } \\
\text { ABTS), antioxidant activity }\end{array}$ & [51] \\
\hline wild genotype of Vaccinium spp. & anthocyanin, polyphenols & $\begin{array}{l}\text { scavenging free radicals (ABTS, } \\
\text { superoxide anion and } \\
\text { hydroxyl radical) }\end{array}$ & [53] \\
\hline $\begin{array}{l}\text { Hypericum perforatum, } \\
\text { Hypericum scabrum }\end{array}$ & $\alpha$-pinene & $\begin{array}{l}\text { scavenging free radicals (DPPH), } \\
\text { inhibition of } \beta \text {-carotene bleaching }\end{array}$ & [54] \\
\hline wild Fragaria genotypes & not mentioned & antioxidant activity & {$[55]$} \\
\hline Ensete superbum & Phenolics and tannin & $\begin{array}{l}\text { scavenging free radicals (DPPH, } \\
\text { ABTS), antioxidant activity }\end{array}$ & [56] \\
\hline Fragaria vesca & phenolics & $\begin{array}{l}\text { scavenging free radicals (DPPH), } \\
\text { antioxidant activity }\end{array}$ & [57] \\
\hline Rosa canina & polyphenols and vitamin $C$ & scavenging free radicals (DPPH) & {$[62]$} \\
\hline Momordica charantia & not mentioned & $\begin{array}{l}\text { scavenging free radicals (DPPH, } \\
\text { hydroxyl radicals), protection } \\
\text { against } \mathrm{Cu}^{2+} \text {-induced } \\
\text { low-density-lipoprotein peroxidation }\end{array}$ & [63] \\
\hline Prunus amygdalus & not mentioned & $\begin{array}{l}\text { scavenging free radicals }(\mathrm{DPPH}) \text {, } \\
\text { reducing power }\end{array}$ & {$[64]$} \\
\hline 2 wild blueberries & polyphenols & $\begin{array}{l}\text { scavenging free radicals (DPPH, } \\
\text { ABTS, oxygen radicals), } \\
\text { antioxidant activity }\end{array}$ & [65] \\
\hline Citrus hystrix & phenolics & $\begin{array}{l}\text { scavenging free radicals (DPPH), } \\
\text { antioxidant activity }\end{array}$ & [66] \\
\hline $\begin{array}{l}\text { Amygdalus lycioides, Amygdalus } \\
\text { kotschyi, Amygdalus pabotti, } \\
\text { Amygdalus trichamygdalus }\end{array}$ & phenolics & $\begin{array}{l}\text { scavenging free radicals (nitrite, } \\
\text { hydrogen peroxide, superoxide } \\
\text { radicals), reducing power }\end{array}$ & [67] \\
\hline Vaccinium miyrtillus & phenolics & $\begin{array}{l}\text { scavenging free radicals (DPPH), } \\
\text { antioxidant activity }\end{array}$ & [68] \\
\hline $\begin{array}{l}\text { Rubus croceacanthus and } \\
\text { Rubus sieboldii }\end{array}$ & anthocyanins, ascorbic acid & scavenging oxygen radicals & [69] \\
\hline
\end{tabular}


Table 1. Cont.

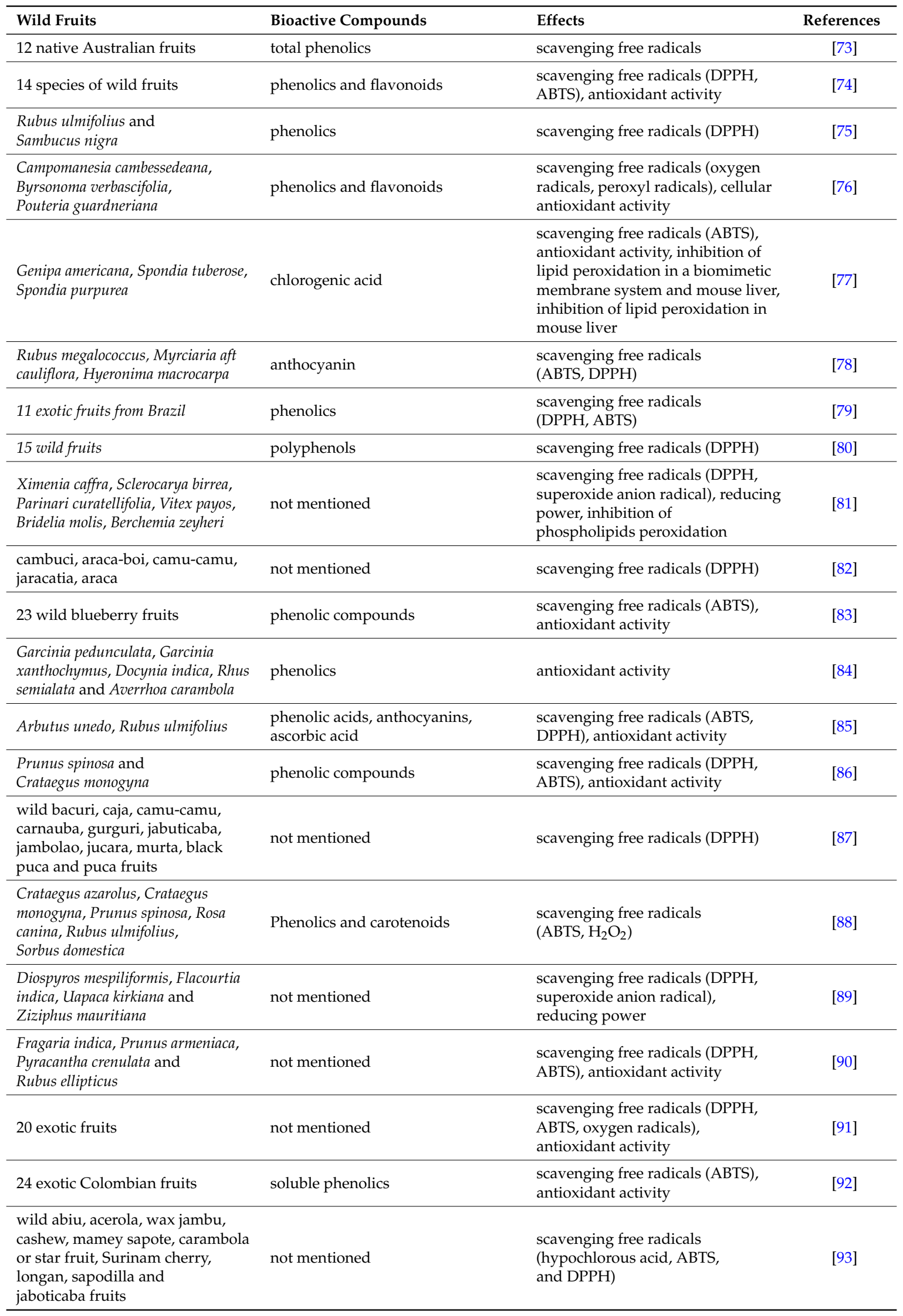


Table 1. Cont.

\begin{tabular}{|c|c|c|c|}
\hline Wild Fruits & Bioactive Compounds & Effects & References \\
\hline $\begin{array}{l}\text { exotic araca-boi, cajamanga, } \\
\text { sirihuela, dovialis, landim, murici, } \\
\text { tomatinho do mato fruits }\end{array}$ & phenolics & $\begin{array}{l}\text { scavenging free radicals (ABTS, } \\
\text { DPPH), antioxidant activity }\end{array}$ & [94] \\
\hline 17 exotic fruits & phenolics and proanthocyanidins & antioxidant activity & [95] \\
\hline $\begin{array}{l}\text { Cornus mas, Prunus spinosa, } \\
\text { Rubus fruticosus }\end{array}$ & polyphenolics & scavenging free radicals & [96] \\
\hline $\begin{array}{l}\text { Salacca edulis Reinw, } \\
\text { Garcinia mangostana }\end{array}$ & phenolics & $\begin{array}{l}\text { hindering the rise in plasma lipids } \\
\text { and decrease of antioxidant activity } \\
\text { in rats fed with cholesterol }\end{array}$ & [97] \\
\hline Vaccinium angustifolium & polyphenols & $\begin{array}{l}\text { improving brain antioxidant } \\
\text { properties in mice (antioxidant } \\
\text { activity, improving ascorbic acid } \\
\text { concentration and glutathione } \\
\text { levels, reducing lipid } \\
\text { peroxidation products) }\end{array}$ & [98] \\
\hline $\begin{array}{l}\text { wild durian, snake fruit } \\
\text { and mangosteen }\end{array}$ & not mentioned & $\begin{array}{l}\text { scavenging free radicals (ABTS, } \\
\text { DPPH), antioxidant activity }\end{array}$ & [99] \\
\hline
\end{tabular}

ABTS: 2,2' -azinobis-3-ethylbenzothiazoline-6-sulphonate; DPPH: 2,2-diphenyl-1-picrylhydrazyl.

Some studies compared the antioxidant activities between different genotypes of a certain species of wild fruit. Fourteen wild mandarin genotypes of Citrus reticulata were assessed for the antioxidant activities and phenolic compounds in the peels [50]. Results showed that antioxidant potency composite (APC) index varied from 58.84 to 98.89 in the studied wild genotypes, and among them, Nieduyeju showed the highest APC index. Furthermore, wild genotypes Guangxihongpisuanju, Nieduyeju, Cupigoushigan, and Daoxianyeju contained more phenolic compounds and exhibited higher antioxidant capacities than the commercial cultivars Satsuma and Ponkan. In another study, ethanol and ethyl acetate extracts of 10 crabapple varieties (Malus wild species) from China were analyzed for the antioxidant activities. Ethyl acetate extract showed higher contents of total phenolic and total flavonoids, and stronger DPPH and ABTS radical scavenging activities than ethanol extract, while ethanol extract had a significantly higher FRAP value $(p<0.01)$ than ethyl acetate extract. Results also showed that whole fruits of wild Malus species, particularly Malus rockii, exhibited stronger antioxidant activity than reported apple peel, indicating that Malus wild species could be rich sources of antioxidants [51]. Papaya, a fruit of the genus Chaenomeles, is an important source of functional food and traditional Chinese herbs. Du et al. evaluated the total polyphenol content (TPC) and antioxidant potential of five wild Chaenomeles genotypes [52]. Among them, the fruit of $C$. speciosa showed the highest free radical scavenging abilities by ABTS and FRAP assays while the $C$. thibetica extract was less effective. $C$. sinensis showed the highest DPPH scavenging capacity. Among them, DPPH values of extracts from four genotypes, C. sinensis $(6.48 \pm 0.23), C$. speciosa $(5.63 \pm 0.17)$, C. thibetica $(4.89 \pm 0.21)$, and C. cathayensis $(4.88 \pm 0.25)$, were higher than Trolox (3.79 \pm 0.07$)$. In addition, wild genotypes of Vaccinium berries were evaluated for their differences in bioactivity on oxidative protection and minimum dosage to have a significant action [53]. Wild Vaccinium extracts are 3.04-fold more active than cultivated extracts by $\mathrm{EC}_{50}$, indicating that wild Vaccinium berries possessed stronger antioxidant activity than the cultivated ones. The results of six antioxidant assays showed a good relationship with anthocyanin and polyphenol content. In addition, the essential oil (EO) compositions and antioxidant activities of wild fruits Hypericum perforatum and Hypericum scabrum were analyzed. It was found that the antioxidant abilities of the EOs evaluated by $\beta$-carotene bleaching and DPPH assays might be due to their $\alpha$-pinene contents [54]. Furthermore, the total phenolics and antioxidant activity of a group of Fragaria genotypes were determined and compared with the commercial genotype F. xananassa. The antioxidant capacity in the wild material was about three-fold higher than the commercial material [55]. In another study, wild bananas (Ensete superbum) had higher contents of phenolics and tannins, higher DPPH, ABTS, and FRAP activities than commercial ones [56]. Furthermore, all 
the investigated wild strawberry accessions (Fragaria vesca) showed higher antioxidant activity than the commercial cultivar (Camarosa) [57]. Results of another study indicated a significant difference between different wild strawberry fruits in their abilities to scavenge DPPH radicals [58]. Furthermore, a wild strawberry showed higher total phenolics and antioxidant activity than those cultivated samples [59]. Two wild raspberries also showed high antioxidant activity by FRAP, ABTS, and DPPH assays [60]. Besides, six genotypes of Diospyros kaki fruits were analyzed, and wild genotype D. kaki var. Silvestris Makino showed the highest content of phenolics and strongest antioxidant activity [61]. Additionally, eight wild genotypes of Rosa canina fruit showed great antioxidant activity, with a good relationship with total polyphenols and vitamin C content [62]. Several genotypes of wild bitter gourd (Momordica charantia) from Taiwan showed protective activity against $\mathrm{Cu}^{2+}$-induced low-density-lipoprotein peroxidation [63]. Furthermore, fruits of 10 wild almonds (Prunus amygdalus) were assessed, and two kinds (A. pabotti Browicz and A. orientalis Duhamel) exhibited the best antioxidant properties [64]. In addition, four wild almond species from Iran showed strong antioxidant activity [67]. Moreover, two wild blueberries showed higher total polyphenols content and antioxidant activity than three cultivated ones [65]. In addition, the fruit of the wild lime (Citrus hystrix) had higher antioxidant, flavonoid, and phenolic contents than cultivated ones [66]. In another study, wild blueberry exhibited stronger antioxidant activity than four cultivated ones [68]. Two wild berries showed potent antioxidant activity by ORAC assay [69]. However, in another study, the antioxidant capacities of fruits of wild and cultivated cranberries were similar, without a statistically significant difference $(p<0.05)$ [70]. Furthermore, wild cranberries exhibited a lower average antioxidant capacity than cultivated berries [71]. Similarly, hydroalcoholic extracts of wild murtilla (Ugni molinae) fruit showed weaker DPPH. and ABTS. scavenging capacity than cultivated ones [72].

Some studies screened different species of wild fruits for their antioxidant activities. In a study, 12 native Australian fruits were screened for the antioxidant activities and contents of phenolics, anthocyanins, and ascorbic acid, using ABTS and photochemiluminescence (PCL) assays [73]. Among them, five fruits exhibited significant stronger radical scavenging abilities (3.1- to 5.2-fold and 1.2- to 4.2-fold for ABTS and PCL assays, respectively) than blueberry (used as control). Six studied fruits showed higher total phenolics content (2.5- to 3.9-fold of control). Moreover, the Kakadu plum had the highest content of ascorbic acid (938-fold of control). These fruits could be a novel rich source of natural antioxidants. In another study, Fu et al. evaluated the antioxidant abilities of 56 exotic fruits from south China. Results of FRAP and ABTS. ${ }^{+}$(expressed as TEAC value) assays showed that these fruits generally possessed high antioxidant capacities, which were strongly correlated with total phenolic content, indicating that phenolic compounds mainly contributed to their antioxidant activities [3]. In another study, 14 wild fruits were assessed for their antioxidant activities [74]. Results showed that among all the tested fruits, the acetone extract of Detarium microcarpum fruit possessed the highest DPPH free radical scavenging capacity, FRAP values, and ABTS free radical scavenging capacity. Meanwhile, antioxidant activities were strongly correlated with total phenolic and flavonoid levels. In addition, antioxidant activity was evaluated for seed residue extracts of wild Rubus ulmifolius and Sambucus nigra fruits [75]. The results of a DPPH assay showed significant antioxidant capacities of the extracts from all fruit seed residues. Meanwhile, the methanolic extract of Rubus seed residue exhibited a stronger antioxidant activity than that of Sambucus seed. In another study, Malta et al. tested the antioxidant activities of three wild cerrado fruits called gabiroba (Campomanesia cambessedeana), murici (Byrsonoma verbascifolia), and guapeva (Pouteria guardneriana) [76]. Results showed that gabiroba fruit was the richest source of total phenolics, and exhibited the highest antioxidant activity for both assays (ORAC, peroxyl radical scavenging capacity assays). In addition, ethanol extracts of three wild fruits, genipap (Genipa americana), umbu (Spondia tuberosa), and siriguela (Spondia purpurea), were analyzed for their antioxidant capacities. Siriguela and umbu (seeds and peels) extracts exhibited the highest antioxidant activities. Results of lipid peroxidation assay showed that pulp of genipap could be a promising source of antioxidant [77]. Furthermore, three wild fruits, Rubus megalococcus, Myrciaria aft cauliflora, and Hyeronima macrocarpa, were tested for their 
antioxidant activities. Results showed that the anthocyanin-rich extracts of Hyeronima macrocarpa exhibited stronger radical scavenging activity than the other extracts [78]. Moreover, 11 fresh exotic fruits from Brazil were analyzed for antioxidant activities by DPPH and ABTS assays. All the fruits showed considerable antioxidant activity, and the phenolic contents were positively correlated with total antioxidant activity by ABTS $(R=0.94, p \leqslant 0.001)$ and DPPH $(R=0.88, p \leqslant 0.001)$ assays [79]. In another study, 15 wild fruits were screened for their antioxidant activities [80]. Results showed that fruits of wild Terminalia bellirica, Terminalia chebula, Phyllanthus emblica, and Spondias pinnata possessed the strongest antioxidant activity based on the DPPH assay. Moreover, Spondias pinnata was more effective ( $16 \%$ radical scavenging activity) than vitamin C ( $5 \%$ radical scavenging activity), both at $5 \mu \mathrm{g} / \mathrm{mL}$. Additionally, the peel and pulp of six wild fruits, sour plum (Ximenia caffra), marula (Sclerocarya birrea), mobola plum (Parinari curatellifolia), chocolate berry (Vitex payos), velvet sweet-berry (Bridelia molis), and red ivory (Berchemia zeyheri), were tested for their antioxidant activities. Both the peel and pulp of sour plum showed higher reducing capacities than all the other fruits, while velvet sweet-berry, the peel and pulp of sour plum, and chocolate berry peel showed high inhibitory effects on phospholipid peroxidation at high concentrations [81]. Additionally, the exotic Camu-camu fruit (Myrciaria dubia) presented the highest DPPH-scavenging capacity of all the fruits tested [82]. Furthermore, several wild blackberry fruit samples showed strong antioxidant activity with rich phenolic profile and content [83]. In another study, results showed the order of the antioxidant activity of five wild fruits was Rhus semialata $>$ Docynia indica $>$ Garcinia xanthochymus $>$ Averrhoa carambola $>$ Garcinia pedunculata [84]. In addition, wild Arbustus unedo fruit showed higher Folin-Ciocalteu values, vitamin C, and phenolic content than Rubus ulmifolius fruit [85]. Wild blackthorn (Prunus spinose) fruit exhibited higher antioxidant capacity than hawthorn (Crataegus monogyna) fruit [86]. In addition, several exotic tropical fruits (bacuri, caja, camu-camu, carnauba, gurguri, jabuticaba, jambolao, jucara, murta, black puca, and puca) showed strong antioxidant activity in a DPPH assay [87]. Additionally, fruit of wild Rosa canina showed higher efficacy towards ABTS. and $\mathrm{H}_{2} \mathrm{O}_{2}$ species than other tested wild fruits [88]. Moreover, methanolic extracts from jackal berry (Diospyros mespiliformis) showed higher DPPH radical scavenging capacity compared with other tested fruits [89]. In addition, fruits of Fragaria indica, Prunus armeniaca, Pyracantha crenulata, and Rubus ellipticus showed strong antioxidant activity [90]. Furthermore, 20 exotic fruits showed high antioxidant activity [91]. In addition, 24 exotic fruits were assessed, and the highest antioxidant activity and content of total phenolics were observed in banana passion fruits (Passiflora tarminiana and Passiflora mollisima) [92]. Similarly, exotic acerola showed the highest antioxidant values in the 10 exotic fruits investigated [93], and exotic dovialis showed the strongest antioxidant activity among the investigated exotic fruits [94]. In addition, wild Psidium cattleianum, Averrhoa carambola, Syzygium cumini, and Psidium guajava fruits showed the highest antioxidant capacities among the 17 exotic fruits from Mauritius [95]. Furthermore, polyphenolic extracts of three wild red berry fruits (Cornus mas, Prunus spinose, and Rubus fruticosus) showed strong scavenging ability on DPPH radical ( $\mathrm{IC}_{50}$ values of 22.19 to $31.18 \mathrm{~mL} / \mathrm{g}$ ) [96].

\subsubsection{In Vivo Studies}

Several studies also evaluated the antioxidant activities of some wild fruits in vivo. In a study, wild snake fruit (Salacca edulis) and mangosteen (Garcinia mangostana) were analyzed for their influences on antioxidant activities and plasma lipids in rats fed with cholesterol. The rats were fed with diets supplemented with snake fruit and mangosteen for four weeks, and it was found that the increase in plasma lipids and the decline in antioxidant activity were both hindered, and snake fruit was more effective than mangosteen [97]. In another study, the effect of a polyphenol-rich extract (PrB) of Vaccinium angustifolium (wild blueberries) on brain oxidative status in adult, male, 3-4-month-old Balb-c mice was examined. Antioxidant status was determined by FRAP assay and levels of ascorbic acid, malondialdehyde, and reduced glutathione in whole brain homogenates. Lipid peroxidation products were decreased (38\% and 79\%) and brain ascorbic acid level was increased $(21 \%$ and $64 \%)$ in both PrB30- and PrB60-treated groups. An increased glutathione level (28\%) was observed in 
the PrB60-treated group. The results indicated that the fruit possessed strong brain antioxidant property [98]. In addition, the in vivo antioxidant activities of rare exotic Thai fruits, durian, snake fruit, and mangosteen, were investigated. Results showed that plasma lipid profile and antioxidant activity in rats fed with cholesterol-containing diets were positively influenced by diets supplemented with these exotic fruits [99].

These studies proved that abundant wild fruits could be potential sources of natural antioxidants, thus supporting their full utilization as bioactive elements in the food, pharmaceutical, and cosmetic industries. The antioxidant activity and possible functional components of extracts of some wild fruits are summarized in Table 1.

\subsection{Antimicrobial Activity}

It is well known that various bacterial, fungal, and viral species could cause plant, animal, and human diseases, thereby causing the loss of crops, food spoilage, or even food poisoning that could damage human health $[100,101]$. Hence, it is important to develop natural effective antimicrobial agents. In recent years, wild fruits have exhibited potential antibacterial, antifungal, and antiviral activities in several studies.

\subsubsection{Antibacterial and Antifungal Activities}

Some studies analyzed the antimicrobial activity of a certain species of wild fruit. An aqueous extract of wild fruit Nitraria retusa was tested for inhibition of microbial growth in beef patties. The results showed that the extract possessed strong antimicrobial activity against Salmonella typhimurium, Klebsiella pneumonia, and Bacillus thuringiensis [102]. In addition, extracts of wild yellow azarole fruit peel showed considerable antibacterial activity, especially against Staphylococcus aureus and Streptococcus faecalis [103]. Moreover, methanol and n-hexane extracts from fruits of wild mahaleb cherry (Prunus mahaleb) were screened by measuring their inhibitory activity on several bacteria (Escherichia coli, Pseudomonas aeruginosa, Proteus mirabilis, K. pneumoniae, Acinetobacter baumannii, S. aureus, Enterococcus faecalis, and Bacillus subtilis), as well as several fungi (Candida albicans, Candida parapsilosis, Candida tropicalis, and Candida krusei). The extracts showed antibacterial activity against both Gram (+) bacteria and Gram (-) bacteria tested, and the methanol and n-hexane extracts showed antifungal activity against C. krusei [104]. Moreover, a fresh fruit extract of the wild plant Clematis apiifolia exhibited minimum inhibitory concentrations (MIC) in the vicinity of $0.1 \%$ against various yeasts and non-lactic acid bacteria of $\leqslant 0.4 \%$. MICs against lactic acid bacteria were about $2.0 \%$. Results indicated that this fruit was even more effective in antibacterial activity than garlic, which has great antibacterial properties. Furthermore, the principal antimicrobial compound of C. apiifolia was isolated and identified as protoanemonin. The researchers suggested that the antimicrobial compound of $C$. apiifolia inhibited microorganisms by reacting with sulfhydryl groups of cellular proteins [105]. Furthermore, the antimicrobial activities of the essential oil hydrodistilled from wild pepper fruits were evaluated. Results showed medium inhibitory effect against the Gram $(+)$ species E. faecalis, S. aureus, and the yeast C. albicans [59]. Moreover, inhibitory effects on the growth of Mycobacterium tuberculosis $\mathrm{H}(37) \mathrm{Rv}$ was observed in fruits of wild ampalaya (Momordica charantia). The fruits of wild ampalaya showed higher antitubercular activity $(90 \%)$ than that of the cultivated variety $(81 \%)$ [106]. Malek et al. tested the antibacterial activities of oils separated from the fruit of Scabiosa arenaria, a wild plant growing in Tunisia. The 16 Gram (+) and Gram (-) bacteria and four Candida species were used. The oils exhibited significant inhibitory activities against these bacterial and Candida species, superior to thymol, which was used as a positive control [107].

Carissa opaca is a wild plant used widely in ethnomedicine. Thirty-four strains of Gram (+) and Gram (-) bacteria were used to determine the antibacterial activities of ethanol extracts of the fruits. The results exhibited a broad spectrum of efficacy [108]. Additionally, crude oils from ripe and unripe wild olive fruits were proved to have antibacterial activity against some of the Gram (+) and Gram (-) bacterial strains [109]. In another study, antimicrobial properties of extracts of fruits from 
wild melon (Citrullus lanatus) were tested. The researchers tested antimicrobial properties of crude chloroform, hexane, and ethanol extracts against five bacteria (E. coli, S. aureus, P. aeruginosa, B. subtilis, and Proteus vulgaris) and two fungi (Aspergillus nigar and C. albican). It was found that a chloroform extract of the fruit showed the highest antibacterial activity, while an ethanol extract of the fruit pulp exhibited the highest antifungal activity. It is worth mentioning that the fruit of this plant was as potent as standard antimicrobial drugs (clotrimazole and gentamici) against certain microorganisms [110]. Moreover, another study showed that wild strawberry guavas (Psidium cattleianum) possessed better antimicrobial activity than common guavas [111]. In addition, different wild clones of European cranberry were investigated for their antimicrobial activities. Results showed that extracts of wild European cranberry had inhibitory effects against the growth of varieties of human pathogenic bacteria, both Gram (+) and gram (-). Among them, the most sensitive bacteria were Listeria monocytogenes and Enterococcus faecalis (average inhibition zones of 20.35 and $19.71 \mathrm{~mm}$, respectively), and S. typhimurium and S. aureus showed moderate resistance [112].

Some studies compared the antimicrobial activity between different species of wild fruits. In a study, polyphenolic extracts of three wild red berry fruits, European cornel (Cornus mas), blackthorn (Prunus spinosa), and blackberry (Rubus fruticosus), were assessed for their antimicrobial activities by the disc diffusion method. Almost all the tested bacterial strains (such as E. coli, P. aeruginosa, and Salmonella enteritidis) were inhibited by all extracts. S. enteritidis was the most sensitive among Gram $(-)$ bacteria, while S. aureus was the most sensitive among Gram (+) bacteria. Blackthorn extract showed slightly higher antimicrobial activity compared with the other tested extracts [96]. In addition, Turker et al. tested the antimicrobial activity of eight wild fruits grown in Turkey [113]. Results showed that fresh fruits of wayfaring tree, firethorn, and hawthorn showed the highest antibacterial activity. In addition, ethanol extracts of these fruits exhibited strong inhibitory effects on S. aureus, Staphylococcus siepidermidis, and Streptococcus pyogenes [113]. Furthermore, fruits of three wild plants growing in Mexico, namely nanchi (Byrsonima crassifolia), arrayan (Psidium sartorianum), and ayale (Crescentia alata), were analyzed by Pio-Leon et al. They not only measured their antibacterial activities against 21 human pathogenic bacteria by the micro-dilution assay, but also established the minimum inhibitory concentration (MIC) and minimum bactericide concentration (MBC). Results showed that methanol extracts of arrayan exhibited the highest activity against the Gram (+) bacteria, being most sensitive to $S$. aureus. Meanwhile, hexane extracts of arrayan and ayale exhibited the highest inhibitory effects on enterobacteria (E. coli, Salmonella spp., and Shigella spp.) [114]. Moreover, it was found that essential oils isolated from the fruits of wild Hypericum perforatum and Hypericum scabrum exhibited higher antimicrobial activity against $S$. aureus and E. coli than their main constituent, $\alpha$-pinene [41]. Additionally, methanol and hexane extracts from a pulp of wild tamarind fruit (Tamarindus indica) were tested for their inhibitory activities on human pathogenic microorganisms including five bacteria and three fungi. All the bacterial strains showed sensitivity to both extracts, while only Penicillium species were sensitive to hexane extract [115]. In addition, several water and methanol extracts of the 16 cultivars selected from Taiwanese indigenous wild bitter gourd (Momordica charantia) showed inhibitory activity against the growth of E. coli and Salmonella enterica [116]. Results of another study revealed that a petroleum ether extract of wild Atriplex inflata fruits possessed high inhibitory activity against Botrytis cinerea [117].

\subsubsection{Antiviral Activity}

Several wild fruits have exhibited antiviral activity. Knox et al. detected antiviral properties of crude extracts of wild Kurokarin (Ribes nigrum) fruit against influenza virus types A and B (VIA and VIB). At a concentration of $3.2 \mu \mathrm{g} / \mathrm{mL}$, plaque formation of both IVA and IVB was inhibited by the extract by $50 \%\left(\mathrm{IC}_{50}\right)$. Additionally, when treating the host cells with 10 and $100 \mu \mathrm{g} / \mathrm{mL}$ of the extract for $6 \mathrm{~h}$ after infection, the growth of IVA could be completely suppressed. Virus titers in culture fluids of the cells were completely suppressed after treatment with $100 \mu \mathrm{g} / \mathrm{mL}$ of Kurokarin extract for $1 \mathrm{~h}$ after infection of 8 to $9 \mathrm{~h}$, indicating that the extract inhibited the virus release from the infected 
cells [118]. Furthermore, extracts of a series of wild berry fruit from Bulgaria possessed great antiviral activities [119]. Four wild berries, strawberry, raspberry, bilberry, and lingonberry, were tested for their antiviral properties against some important human pathogens, poliovirus type 1 (PV-1), coxsackievirus B1 (CV-B1), human respiratory syncytial virus A2 (HRSV-A2), and influenza virus (A/H3N2), by virus cytopathic effect inhibition test. It was revealed that extracts of all berry fruits suppressed proliferation of CV-B1 and influenza virus A/H3N2. Meanwhile, anthocyanin fractions of all wild berries showed a considerable inhibitory effect against the replication of influenza virus A/H3N2.

These studies proved that wild fruits could function as potent antibacterial, antifungal, and antiviral agents. The antimicrobial activities of some wild fruits are summarized in Table 2.

Table 2. Antimicrobial activities of some wild fruits.

\begin{tabular}{|c|c|c|c|}
\hline Wild Fruits & Bioactive Compounds & Effects & References \\
\hline $\begin{array}{l}\text { Hypericum perforatum, } \\
\text { Hypericum scabrum }\end{array}$ & not mentioned & inhibition of S. aureus and E. coli & [54] \\
\hline $\begin{array}{l}\text { Cornus mas, Prunus spinosa, } \\
\text { Rubus fruticosus }\end{array}$ & polyphenols & $\begin{array}{l}\text { inhibition of all the tested } \\
\text { bacterial strains }\end{array}$ & [96] \\
\hline Piper capense & not mentioned & $\begin{array}{l}\text { inhibition of } S \text {. aureus, E. faecalis, } \\
\text { and } C \text {. albicans }\end{array}$ & [45] \\
\hline Nitraria retusa & not mentioned & $\begin{array}{l}\text { inhibition of S. typhimurium, } \\
\text { K. pneumonia, and B. thuringiensis }\end{array}$ & [102] \\
\hline Crataegus azarolus & phenolics & inhibition of S. aureus and S. faecalis & [103] \\
\hline Prunus mahaleb & not mentioned & $\begin{array}{l}\text { inhibition of some Gram }(+) \text { and } \\
\text { Gram }(-) \text { bacteria and fungi }\end{array}$ & [104] \\
\hline Clematis apiifolia & protoanemonin & $\begin{array}{l}\text { inhibition of various yeasts and } \\
\text { non-lactic acid bacteria }\end{array}$ & [105] \\
\hline Momordica charantia & not mentioned & $\begin{array}{l}\text { inhibition of } \\
\text { Mycobacterium tuberculosis }\end{array}$ & [106] \\
\hline Scabiosa arenaria & not mentioned & $\begin{array}{l}\text { inhibition of some bacteria, Candida } \\
\text { species, and phytopathogenic fungi }\end{array}$ & [107] \\
\hline Carissa opaca & not mentioned & inhibition of some bacteria & [108] \\
\hline Olea ferruginea & not mentioned & $\begin{array}{l}\text { inhibition of some Gram }(+) \text { and } \\
\text { Gram }(-) \text { bacteria }\end{array}$ & [109] \\
\hline Citrullus lanatus & not mentioned & $\begin{array}{l}\text { inhibition of S. aureus, B. subtilis, } \\
\text { P. valgaris, and P. aerguinosa }\end{array}$ & [110] \\
\hline Psidium cattleianum & not mentioned & inhibition of B. subtilis and S. aureus & [111] \\
\hline Ribes nigrum L. & not mentioned & $\begin{array}{l}\text { inhibition influenza virus types } \\
A \text { and B }\end{array}$ & [118] \\
\hline $\begin{array}{l}\text { Viburnum lantana, Pyracantha } \\
\text { coccinea, Crataegus monogyna }\end{array}$ & not mentioned & $\begin{array}{l}\text { inhibition of S. aureus, S. epidermidis, } \\
\text { and S. pyogenes }\end{array}$ & [113] \\
\hline $\begin{array}{l}\text { Byrsonima crassifolia, Psidium } \\
\text { sartorianum, Crescentia alata }\end{array}$ & not mentioned & $\begin{array}{l}\text { inhibition of E. coli, Salmonella spp., } \\
\text { Shigella spp., and S. aureus }\end{array}$ & [114] \\
\hline Tamarindus indica & not mentioned & $\begin{array}{l}\text { inhibition of some human } \\
\text { pathogenic microorganisms }\end{array}$ & [115] \\
\hline Momordica charantia & not mentioned & $\begin{array}{l}\text { inhibition of E. coli and } \\
\text { Salmonella enterica }\end{array}$ & [116] \\
\hline Atriplex inflata & not mentioned & inhibition of Botrytis cinerea & [117] \\
\hline $\begin{array}{l}\text { Fragaria vesca, Rubus idaeus, } \\
\text { Vaccinium myrtillis, } \\
\text { Vaccinium vitis-idaea }\end{array}$ & anthocyanins & $\begin{array}{l}\text { inhibition of the replication of } \\
\text { coxsackie virus B1 and influenza } \\
\text { virus A/H3N2 }\end{array}$ & [119] \\
\hline wild European cranberry & not mentioned & $\begin{array}{l}\text { inhibition of E. coli and } \\
\text { S. typhimurium, E. faecalis, Listeria } \\
\text { monocytogenes, S. aureus, and } \\
\text { B. subtilis }\end{array}$ & [112] \\
\hline
\end{tabular}




\subsection{Anti-Inflammatory Activity}

Inflammation is closely related to various diseases, such as atherosclerosis, heart disease, stroke, cancer, diabetes mellitus, bone arthritis, asthma, migraine pain, periodontitis, irritable bowel syndrome, and chronic fatigue syndrome. Currently, drugs used to treat chronic inflammatory diseases are mainly various nonsteroidal drugs, which may exert side effects [120]. Therefore, the development of effective and natural sources of anti-inflammatory products has gained increasing attention. Evidence accumulated in recent years pointed out that several kinds of wild fruits possess anti-inflammatory activities, through various mechanisms of action.

Nitric oxide (NO) is a marker of late inflammation formed during activation of inducible nitric oxide synthase (iNOS) [121], and chemokine (C-C motif) ligand 20 (CCL20) is an important chemokine for immune and inflammatory response [122]. Therefore, the inhibition of NO and CCL20 is an indicator of possible anti-inflammatory properties. In the research conducted by Fazio et al., in vitro anti-inflammatory activities of the methanol extracts from the seeds of wild blackberry (Rubus ulmifolius) and elderberry (Sambucus nigra) were analyzed [75]. They firstly evaluated the seeds' ability to inhibit lipopolysaccharide (LPS) induced NO production in mouse macrophage cell line RAW264.7 macrophages. Results showed that wild blackberry extract decreased NO release with almost $60 \%$ inhibition at the highest dose $(50 \mu \mathrm{g} / \mathrm{mL})$. Meanwhile, it showed a concentration-dependent effect. Subsequently, the influence of both extracts on macrophage-inflammatory protein-3 $\alpha /$ CCL20 were evaluated. Wild blackberry extract decreased CCL20 production in a concentration-dependent manner, with a more than $90 \%$ inhibition at $50 \mu \mathrm{g} / \mathrm{mL}$. By comparison, wild elderberry extract did not show a significant effect on decreasing either NO or CCL20 production. The results confirmed that wild blackberry possessed a strong anti-inflammatory activity.

Metabolites of the 5-lipoxygenase (5-LOX) pathway are important mediators of inflammation. LOX and its metabolites are shown to play a vital part in tumor formation and cancer metastasis. In some cancer cells, such as prostate, lung, colon, and breast, high expression of 5-LOX was found. In one study, the anti-inflammatory activity of Ziziphus mistol ripe berries, an exotic Argentinean fruit, was tested. The three tested extracts (ethanolic mistol extraction, aqueous mistol extraction, and acetone water mistol extract) were obtained after two different processes: boiling and hydroalcoholic extraction. They determined LOX activity to evaluate anti-inflammatory activity. In working conditions, only an ethanolic extract exhibited inhibition of LOX activity $\left(\mathrm{IC}_{50}=183.80 \mu \mathrm{g}\right.$ gallic acid equivalents $(\mathrm{GAE}) / \mathrm{mL}$ ), while an aqueous extract showed no inhibitory effect at the tested concentrations (until $45.08 \mu \mathrm{g} \mathrm{GAE} / \mathrm{mL}$ ). These results suggested that bioactive compounds might be thermolabile, yet Ziziphus mistol ripe berries still had potent anti-inflammatory activity [30].

Cyclooxygenase-2 (COX-2) expression is an important pro-inflammatory response. Several studies have confirmed that COX-2, an important inflammatory mediator, is closely related to the occurrence and development of diabetes mellitus and diabetic nephropathy. Therefore, the inhibition of COX-2 is an indicator of possible anti-inflammatory properties. A study analyzed the anti-inflammatory activity of three wild Jamaica-grown fruits species (Rubus jamaicensis, Rubus rosifolius, and Rubus racemosus) and three wild Michigan-grown species (Rubus acuminatus, Rubus idaeus cv., and Rubus idaeus cv.). The COX-1 and COX-2 enzyme inhibitory activities were measured by monitoring the initial rate of $\mathrm{O}_{2}$ uptake. Aspirin, Celebrex, and Vioxx were used as positive controls. Results showed that all the hexane extracts of the Jamaica-grown Rubus berries were COX-active, inhibiting COX-2 by $18 \%-33 \%$, while the Michigan-grown Rubus extracts were, in general, not COX-active [123]. In another study, eight compounds separated from the ethyl acetate extract of the Rubus rosifolius growing wild in elevated regions in Jamaica were identified as euscaphic acid, 1-b-hydroxyeuscaphic acid, hyptatic acid B, 19 $\alpha$-hydroxyasiatic acid, trachelosperogenin, 4-epi-nigaichigoside F1, nigaichigoside F1, and trachelosperoside B-1 by nuclear magnetic resonance (NMR) spectroscopy. In vitro COX-1 and COX-2 enzyme inhibitory assays were conducted to evaluate anti-inflammatory activity. Euscaphic acid, 1-b-hydroxyeuscaphic acid, and hyptatic acid B showed selective COX-1 enzyme inhibitory activity 
(13\%, 25\%, and $35 \%$ respectively) at $25 \mu \mathrm{g} / \mathrm{mL}$. Similar COX inhibitory activity was demonstrated by compounds 4-epi-nigaichigoside F1 and trachelosperoside B-1, which showed moderate selectivity against the COX-1 enzyme [124]. In addition, the anti-inflammatory activity of Psidium cattleianum (strawberry guava) was analyzed using COX-1 and -2 enzyme inhibitory assays. Results showed that ethyl acetate extract of guava exhibited notable activity (56.4\%) against the COX-2 isoform, followed by methanolic extract (44.1\%) against the COX-1 enzyme at $250 \mu \mathrm{g} / \mathrm{mL}$ [111]. Furthermore, a polyphenol-rich fraction from lowbush cranberry, a wild Alaskan Vaccinium berry, showed effective inhibition of LPS-elicited induction of interleukin-1 $\beta$ (IL-1 $\beta$ ) in RAW 264.7 cells [125]. Some wild fruits are rich in anthocyanins, which are known to possess antioxidant and anti-inflammatory activities. A study evaluated the inhibitory effects of wild blackberries on pro-inflammatory responses (NO production, iNOS expression, COX-2 expression, and prostaglandin E2 level). Results demonstrated that dietary consumption of wild blackberries (Rubus spp.) could decrease NO-generated oxidative stress and inhibit the expression of pro-inflammatory proteins, thus protecting the body against oxidation- or inflammation-related diseases [120]. The macrophage cell line RAW 264.7 was stimulated by LPS to cause pro-inflammatory responses. Different fractions from wild blackberry genotypes (WB-3, WB-7, WB-10, and WB-11) were tested separately. At $50 \mu \mathrm{M}$ (cyanidin-3-O-glucoside or catechin equivalent), all markers were significantly $(p<0.05)$ inhibited by most fractions. The highest NO inhibition was observed in the anthocyanin-rich fraction from WB-10, the highest inhibitory activity on iNOS expression was presented by proanthocyanidin-rich fractions from the WB-10, and polyphenolic-rich fractions from WB-7 were identified as potent inhibitors of COX-2 expression.

Nuclear factor- $\mathrm{kB}$ (NF-kB) plays an important part in immune, stress, inflammatory, proliferative, and apoptotic responses [126]. The inhibition of NF- $\mathrm{KB}$ is commonly considered as an effective strategy to treat inflammatory disorders [127]. Tumor necrosis factor- $\alpha$ (TNF- $\alpha$ ) and interleukin (IL) are important inflammatory cytokines. In a study, the anti-inflammatory activities of wild lowbush blueberry were investigated. Effects of the phenolic acid (PA) mixture were firstly measured by the inhibition against LPS-induced NF- $\mathrm{KB}$ activation, and results showed that NF- $\kappa \mathrm{B}$ activation was significantly inhibited (by $33.2 \%$ at $4 \mathrm{mg} \mathrm{FBE} / \mathrm{mL}$ ) by PA mixture. Based on the result, a concentration of $4 \mathrm{mg}$ FBE $/ \mathrm{mL}$ was used in TNF- $\alpha$ and IL-6 ELISA. The production of both TNF- $\alpha(36.7 \%)$ and IL-6 (37.5\%) were significantly decreased by the PA mixture. In conclusion, a phenolic acid mixture of lowbush blueberry showed anti-inflammatory activities by inhibiting NF- $\mathrm{KB}$ activation and the production of inflammatory cytokines (TNF- $\alpha$ and IL-6) at a high dose [128]. In addition, Hsu et al. did a relatively comprehensive experiment on the anti-inflammatory property of wild bitter melon (WBM), including both in vitro and in vivo experiments [129]. Inflammation was induced by Propionibacterium acnes. Results showed that in vitro, an ethyl acetate (EA) extract of WBM fruit potently suppressed pro-inflammatory cytokine (IL-8, TNF- $\alpha$, and IL-1 $\beta$ ) and matrix metalloproteinase (MMP)-9 levels in P. acnes-stimulated THP-1 cells. As for in vivo, P. acnes-induced ear swelling and granulomatous inflammation in mice were effectively attenuated by concomitant intradermal injection of EA extract. This study indicated that wild bitter melon could produce an anti-inflammatory effect.

Several subfractions of Aristotelia chilensis have shown a notable inhibition on the 12-deoxyphorbol-13-decanoate (TPA)- induced inflammation in ear of the mouse edema (EC 50 of 0.3 to $11.8 \mu \mathrm{g} / \mathrm{mL}$ ) [130]. In another study conducted by the same researchers, results showed that carrageenan-induced inflammation in the rat paw was inhibited by these samples [131]. Similarly, in the inflammatory pain mice models induced by acetic acid and formalin, abdominal constrictions and the inflammatory phase of nociception were significantly reduced by intraperitoneal administration of a fraction separated from tamarillo (Solanum betaceum), a tropical exotic fruit. The results suggested that the fraction had a possible antinociceptive effect on inflammatory pain models [132].

These studies strongly proved that some wild fruits could be good natural sources of anti-inflammatory materials through different mechanisms of action, such as inhibiting COX-2 and $\mathrm{NF}-\mathrm{kB}$, as well as decreasing NO and CCL20 release. The anti-inflammatory activities of some wild fruits are summarized in Table 3. 
Table 3. Anti-inflammatory activities of some wild fruits.

\begin{tabular}{|c|c|c|c|}
\hline Wild Fruits & Bioactive Compounds & Effects & References \\
\hline Ziziphus mistol & not mentioned & inhibition of LOX activity & [30] \\
\hline $\begin{array}{l}\text { Rubus ulmifolius, } \\
\text { Sambucus nigra }\end{array}$ & not mentioned & $\begin{array}{l}\text { inhibition of LPS-induced } \\
\text { inflammatory mediators } \\
\text { (NO, CCL20) }\end{array}$ & [75] \\
\hline Psidium cattleianum & not mentioned & $\begin{array}{l}\text { inhibition expression of } \\
\text { COX-2 enzyme }\end{array}$ & [111] \\
\hline $\begin{array}{l}\text { wild blueberry } \\
\text { (Rubus spp.) }\end{array}$ & $\begin{array}{l}\text { anthocyanin-rich, } \\
\text { proanthocyanidin-rich, and } \\
\text { polyphenolic-rich fraction }\end{array}$ & $\begin{array}{l}\text { inhibition expression of COX-2, NO, } \\
\text { and iNOS }\end{array}$ & [120] \\
\hline $\begin{array}{l}\text { Rubus jamaicensis, } \text { Rubus } \\
\text { rosifolius, Rubus racemosus }\end{array}$ & not mentioned & $\begin{array}{l}\text { inhibition the expression of COX-1 } \\
\text { and COX-2 enzymes }\end{array}$ & [123] \\
\hline Rubus rosifolius & ursolic acid analogues & $\begin{array}{l}\text { inhibition expression of } \\
\text { COX-1 enzyme }\end{array}$ & [124] \\
\hline $\begin{array}{l}\text { Vaccinium vitis-idaea, } \\
\text { Vaccinium uliginosum }\end{array}$ & polyphenol-rich fraction & $\begin{array}{l}\text { inhibition of LPS-elicited induction } \\
\text { of IL- } 1 \beta \text { in RAW } 264.7 \text { cells }\end{array}$ & [125] \\
\hline Vaccinium angustifolium & phenolic acids & $\begin{array}{l}\text { inhibiting NF- } k \text { B activation and } \\
\text { production of inflammatory } \\
\text { cytokines (TNF- } \alpha \text { and IL- } 6 \text { ) }\end{array}$ & [128] \\
\hline Momordica charantia & phytol and lutein & $\begin{array}{l}\text { suppressing pro-inflammatory } \\
\text { cytokine and MMP-9 levels, } \\
\text { attenuating P. acnes-induced ear } \\
\text { swelling and granulomatous } \\
\text { inflammation in mice }\end{array}$ & [129] \\
\hline Aristotelia chilensis & not mentioned & $\begin{array}{l}\text { inhibition of carrageenan-induced } \\
\text { inflammation in ear of the mouse } \\
\text { edema in TPA inflammation mode }\end{array}$ & {$[130,131]$} \\
\hline Solanum betaceum & not mentioned & $\begin{array}{l}\text { antinociceptive effect on } \\
\text { inflammatory pain mice models }\end{array}$ & [132] \\
\hline
\end{tabular}

LOX: lipoxygenase; LPS: lipopolysaccharide; NO: nitric oxide; COX-2: cyclooxygenase-2; iNOS: inducible nitric oxide synthase; TNF: Tumor necrosis factor, NF- $\mathrm{B}$ : nuclear factor- $\mathrm{kB}$; MMP: matrix metalloproteinase; TPA: 12-deoxyphorbol-13-decanoate; IL-1: interleukin-1; RAW 264.7: mouse macrophage cell line.

\subsection{Anticancer Activity}

Cancer is known as a major cause of death all over the world. A relationship between fruit intake and a reduced risk of cancer has been found $[133,134]$. Various natural products, such as fruits, vegetables, and herbal plants, have been widely proved to possess antiproliferative activities [135-137]. Several wild fruits, such as wild red raspberry from Jamaica, and wild blueberry, have been proven to possess anticancer activities against breast, colon, prostate, and cervical cancer cells.

Malta et al. tested the inhibitory activity on tumor cell proliferation of three kinds of exotic Brazilian fruits, gabiroba (Campomanesia cambessedeana), murici (Byrsonoma verbascifolia), and guapeva (Pouteria guardneriana), by the MTS assay [77]. The gabiroba, murici, and the pulp of guapeva inhibited growth of HepG2 cell in a dose-dependent manner, with $\mathrm{EC}_{50}$ values of $40.7 \pm 4.8,173.6 \pm 18.2$, and $37.9 \pm 2.2 \mathrm{mg} / \mathrm{mL}$, respectively. The extracts were nontoxic at the concentrations used in the experiments. In another study, hyptatic acid B and 4-epi-nigaichigoside F1 compounds separated from ethyl acetate extract of wild Rubus fruits inhibited the growth of human colon tumor cells by $56 \%$ and $40 \%$, respectively [124]. In another study, eight different extracts of each wild fruit were tested for anticancer activity. Results showed that the greatest anticancer activity was obtained from a cold water extract of fresh R. caesius fruit (100\% inhibition), followed by cold and hot ethanol extracts of fresh V. lantana fruit (90.5\% and $95.2 \%$ inhibition, respectively) [114]. 
Proanthocyanidin is a general term for a large class of polyphenols, which is composed of catechin, epicatechin, and epicatechin gallate in forms of different degrees of polymerization (DPn). Some studies have proved that proanthocyanidin possessed various kinds of bioactivities, such as antioxidant and anticancer activities, preventing hepatic and brain lipid peroxidation and DNA damage in animals [138]. The antiproliferative activity of proanthocyanidin-rich extracts from wild blueberry (Vaccinium angustifolium) was tested. Results showed that the antiproliferative activity of different fractions was positively correlated with proanthocyanidin content, and the fraction with a DPn of 5.65 showed considerable antiproliferative activity against human prostate and mouse liver cancer cell lines [139]. Results also suggested that antiproliferative activity was associated with high molecular weight proanthocyanidin oligomers from wild blueberry fruits.

Yellow Himalayan raspberry, as a wild edible fruit, was analyzed for antiproliferative activities. Results showed that acetone and methanol extracts exhibited inhibitory effects against human cervical cancer cells (C33A) $\left(\mathrm{EC}_{50}\right.$ at 5.04 and $4.9 \mathrm{mg} / \mathrm{mL}$ fruit concentration respectively), and were nontoxic to normal peripheral blood mononuclear cells at the same time [140]. In addition, three wild species of strawberries (Fragaria virginiana, Fragaria Chiloensis, and Fragaria xananassa) were analyzed for antiproliferative activity. Extracts of the three fruits all significantly inhibited the proliferation of A549 human lung epithelial cancer cells [141]. In another study, Woguem et al. found that the volatile oil from the wild pepper could inhibit the growth of human tumor cells MDA-MB 231 (breast adenocarcinoma), A375 (malignant melanoma), and HCT116 (colon carcinoma), in a concentration-dependent manner [59]. Several kinds of water and methanol extracts of wild bitter gourd also showed similar cytotoxic activities on human fibrosarcoma HT 1080 cells to $10 \mu \mathrm{g} / \mathrm{mL}$ of doxorubicin, which was used as positive control in this study [103]. Finally, the anticancer activities of several wild fruits are summarized in Table 4.

Table 4. Anticancer activities of some wild fruits.

\begin{tabular}{|c|c|c|c|}
\hline Wild Fruits & Bioactive Compounds & Effects & References \\
\hline $\begin{array}{l}\text { Campomanesia cambessedeana, } \\
\text { Byrsonoma verbascifolia, } \\
\text { Pouteria guardneriana }\end{array}$ & phenolic compounds & $\begin{array}{l}\text { inhibiting growth of HepG2 human } \\
\text { liver cancer cells }\end{array}$ & [77] \\
\hline Piper capense & essential oil & $\begin{array}{l}\text { inhibiting growth of human breast } \\
\text { adenocarcinoma, malignant } \\
\text { melanoma, and colon carcinoma cells }\end{array}$ & [45] \\
\hline $\begin{array}{l}\text { Rubus caesius, Viburnum } \\
\text { lantana, Crataegus monogyna, } \\
\text { Crataegus tanacetifolia }\end{array}$ & not mentioned & inhibition of tumor cells & [114] \\
\hline Momordica charantia & not mentioned & $\begin{array}{l}\text { cytotoxic activities on human } \\
\text { fibrosarcoma HT } 1080 \text { cells }\end{array}$ & [117] \\
\hline Rubus rosifolius & $\begin{array}{l}\text { hyptatic acid B, } \\
\text { 4-epi-nigaichigoside F1 }\end{array}$ & inhibiting growth of colon tumor cells & [124] \\
\hline Vaccinium angustifolium & $\begin{array}{l}\text { oligomeric } \\
\text { proanthocyanidins fraction }\end{array}$ & $\begin{array}{l}\text { inhibiting growth of human prostate } \\
\text { and mouse liver cancer cell lines }\end{array}$ & [139] \\
\hline Rubus ellipticus & not mentioned & $\begin{array}{l}\text { inhibiting growth of human cervical } \\
\text { cancer cells (C33A) }\end{array}$ & [140] \\
\hline $\begin{array}{l}\text { Fragaria virginiana, } \\
\text { F. chiloensis, F. xananassa }\end{array}$ & not mentioned & $\begin{array}{l}\text { inhibiting growth of A549 human } \\
\text { lung epithelial cancer cells }\end{array}$ & [141] \\
\hline
\end{tabular}

\subsection{Other Bioactivities of Wild Fruits}

In addition to the biological activities mentioned above, some wild fruits have shown other beneficial health effects.

Some wild fruits have shown anti-acetylcholinesterase activity. The acetylcholinesterase inhibitory activity is a commonly used pharmacological model of Alzheimer's disease. In one 
study, a water extract of Sorbus torminalis (wild service tree) fruit showed moderate ability to inhibit acetylcholinesterase [29]. Similarly, three exotic fruits from Brazil were tested for anti-acetylcholinesterase activities, namely genipap (Genipa americana), umbu (Spondia tuberosa) and siriguela (Spondia purpurea). Results showed that ethanol extracts of genipap pulp and siriguela seed could present a similar inhibitory effect on acetylcholinesterase compared with carbachol (positive control) [77]. In another study, an obvious cognitive enhancement was observed in the experimental mice after short-term intraperitoneal supplementation with a polyphenol-rich extract of wild blueberries (Vaccinium angustifolium) [98]. Researchers found that the brain antioxidant properties of mice were higher and acetylcholinesterase activity was inhibited after the treatment, indicating that bioactive components of wild blueberry are able to affect the brain function of mice in a positive way.

Furthermore, larvicidal/insecticidal activities have been observed in several wild fruits. The researchers evaluated the insecticidal activity of wild Tetradium glabrifolium fruits against Aedes albopictus [142]. Essential oils and three compounds from the fruit showed strong larvicidal activities against the early fourth-instar larvae of $A$. albopictus. In another study, the antigiardial activities of wild watermelon (Citrullus lanatus) fruits were investigated [143]. Results revealed that two compounds from the fruits, cucurbitacin L 2-O- $\beta$-glucoside and cucurbitacin E, had potent antigiardial activity against Giardia lamblia in vitro. Meanwhile, all the extracts, including petroleum ether, ethyl acetate, and butanol crude extracts, were active against Giardia lamblia. The results indicated that this fruit might be a potential new resource for the control of giardiasis. Zanthoxylum schinifolium is a traditional wild Chinese medicinal plant. Researchers found that essential oils of the fruits exhibited strong fumigant toxicity against the maize weevil Sitophilus zeamais, a common grain storage insect [144]. Similarly, fruits of another wild Chinese medicinal plant called Carum carvi showed strong fumigant toxicity and contact toxicity against Sitophilus zeamais and Tribolium castaneum adults, which are both common grain storage insects [145].

There was a study proving that $70 \%$ methanol extract of Elaeagnus latifolia, a wild edible fruit, had a promising effect on protecting pUC18 DNA [37]. In addition, a methanol extract of wild Brenania brieyi fruit showed estrogenic effects by doubling the uterine weight and increasing the vaginal epithelial height of female rats [146]. Advanced glycation endproducts (AGE) is an important related pathophysiological feature common to many chronic diseases, such as cardio- and cerebrovascular diseases, diabetes mellitus, and Alzheimer's disease. Inhibitory activity on AGE formation was related to radical scavenging activities. In a study, all samples of wild berries reduced AGE formation in a concentration-dependent way, with a positive correlation to each extract's total phenolic content and, to a lesser degree, total anthocyanin content [147]. Moreover, it has been reported that methanol extracts of wild raspberry fruits had potassium-conservation diuretic activity in experimental rats [148]. The fruit of wild Aristotelia chilensis also showed gastroprotective effects and thus have great potential as nutraceuticals [131].

Other bioactivities of wild fruits are summarized in Table 5. All the bioactivities of wild fruits are displayed in Figure 1. 


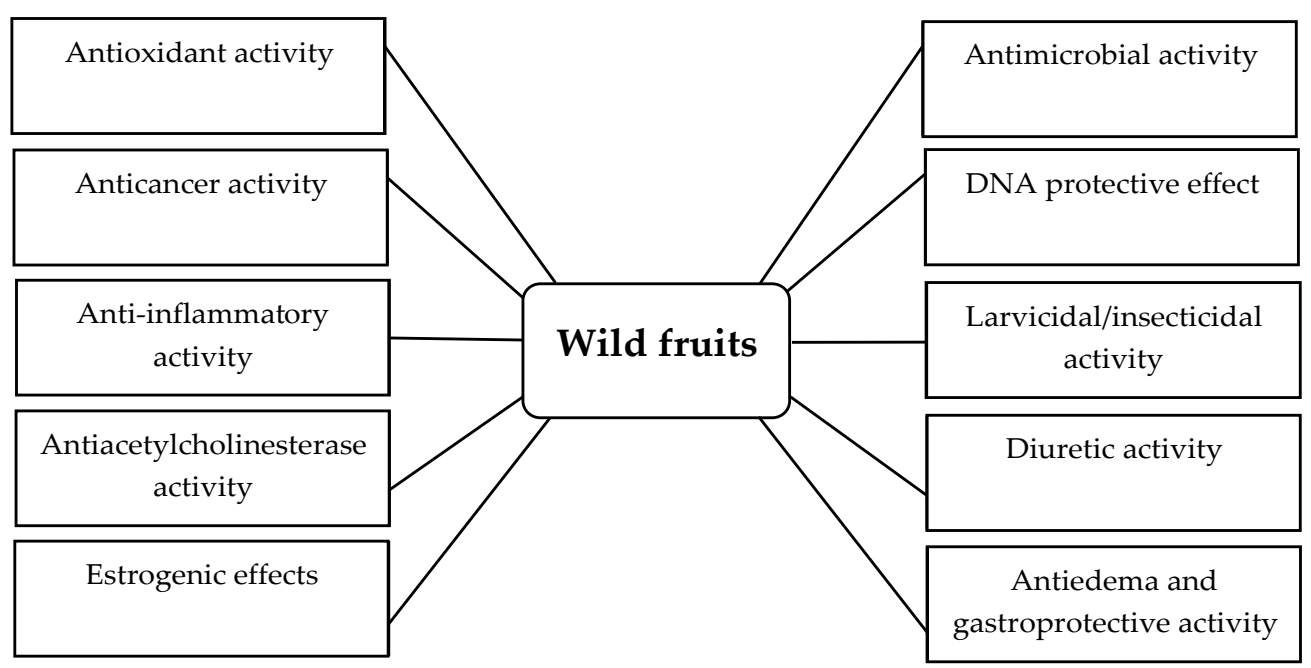

Figure 1. Some bioactivities of wild fruits.

Table 5. Other bioactivities of some wild fruits.

\begin{tabular}{|c|c|c|c|}
\hline Wild Fruits & Bioactive Compounds & Effects & References \\
\hline Sorbus torminalis & not mentioned & antiacetylcholinesterase activity & [29] \\
\hline $\begin{array}{l}\text { Genipa americana, Spondia } \\
\text { tuberosa, Spondia purpurea }\end{array}$ & chlorogenic acid & antiacetylcholinesterase activity & [78] \\
\hline Elaeagnus latifolia & $\begin{array}{l}\text { phenolic and } \\
\text { flavonoid compounds }\end{array}$ & protection of pUC18 DNA & [37] \\
\hline Vaccinium angustifolium & polyphenol-rich extract & $\begin{array}{l}\text { decreasing acetylcholinesterase } \\
\text { activity and enhancing cognition } \\
\text { in adult mice }\end{array}$ & [98] \\
\hline Aristotelia chilensis & $\begin{array}{l}\text { aglycone and } \\
\text { phenolic compounds }\end{array}$ & $\begin{array}{l}\text { inhibition of the carrageenan- } \\
\text { induced inflammation in the paw } \\
\text { rat and gastroprotective activity } \\
\text { in rats }\end{array}$ & [131] \\
\hline Tetradium glabrifolium & $\begin{array}{l}\text { 2-tridecanone, 2-undecanone } \\
\text { and d-limonene }\end{array}$ & $\begin{array}{l}\text { larvicidal activity against the early } \\
\text { fourth-instar larvae of } A \text {. albopictus }\end{array}$ & [142] \\
\hline Citrullus lanatus & $\begin{array}{l}\text { cucurbitacin E, cucurbitacin L } \\
2-O-\beta \text {-glucoside }\end{array}$ & antigiardial activities & [143] \\
\hline Zanthoxylum schinifolium & estragole, linalool and sabinene & $\begin{array}{l}\text { fumigant toxicity against } \\
\text { S. zeamais }\end{array}$ & [144] \\
\hline Carum carvi & (R)-carvone and d-limonene & $\begin{array}{l}\text { contact toxicity against } S \text {. and } \\
\text { T. castaneum adults }\end{array}$ & [145] \\
\hline Brenania brieyi & not mentioned & estrogenic effects & [146] \\
\hline 12 species of wild berries & phenolics, anthocyanins & antiglycation activity & [147] \\
\hline Rubus idaeus & not mentioned & diuretic activity & [148] \\
\hline
\end{tabular}

\section{Bioactivities of Wild Berries}

The berries are an important group of fruits. Berries include members of several families, such as Rosaceae and Ericaceae [149]. It is well established that berries contain high contents of bioactive compounds, such as phenolic acids, anthocyanins, flavonols, and tannins [150,151]. Wild berries are so far underutilized, but they are often equal to or more valuable than commercial berries in terms of their bioactivities and health benefits, such as antioxidant, antimicrobial, anti-inflammatory, and anticancer activities $[78,104,123,139]$. The bioactivities of wild berries involved in this review are summarized in Table 6. 
Table 6. Bioactivities of some wild berries.

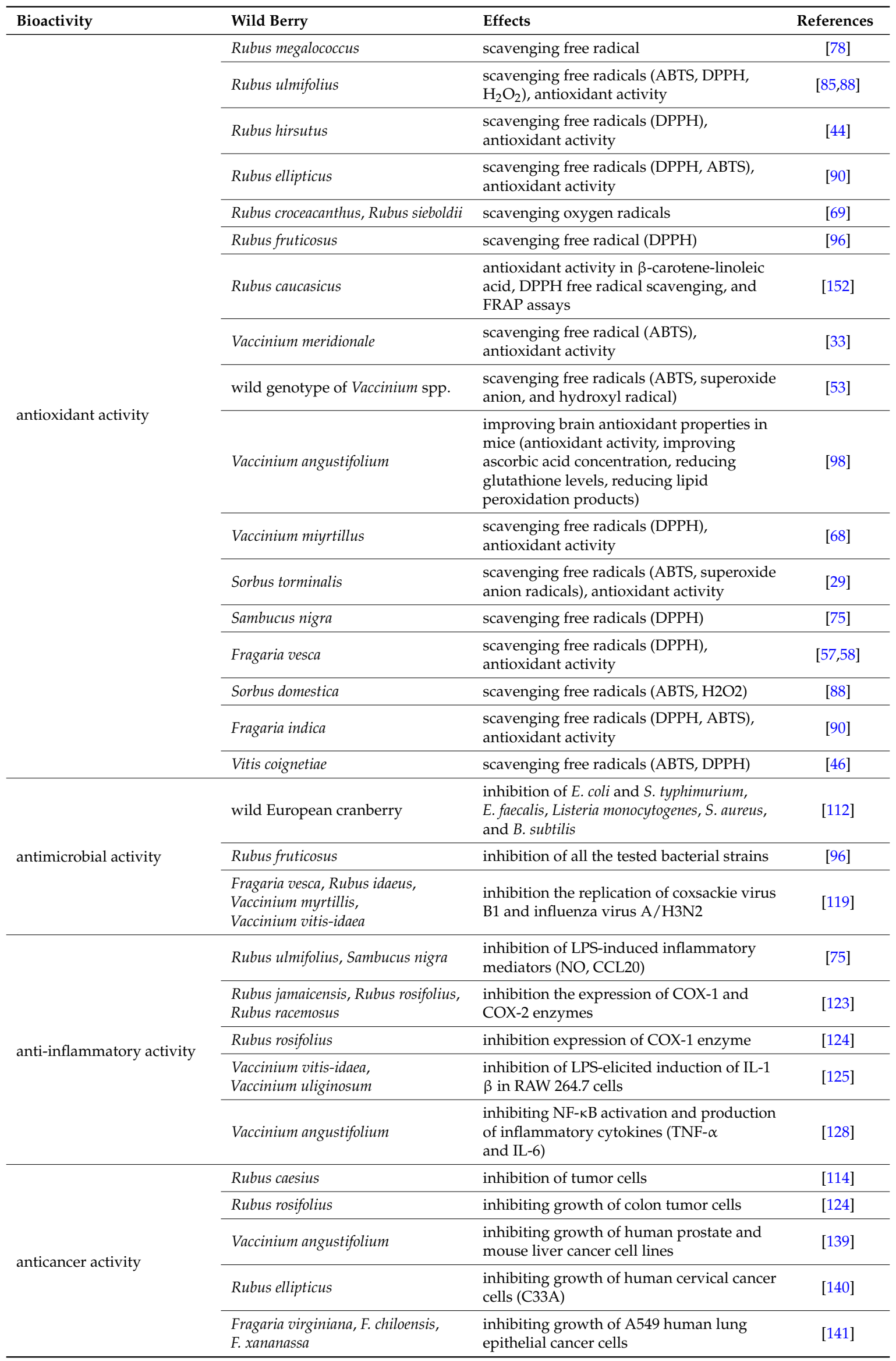




\section{Conclusions}

The special genotype and formative environment create unique and abundant ingredients with health benefits in wild fruits. When a wild species is domesticated, the biological activities might decrease. In addition, wild fruits should not be excessively exploited, as this could cause a depauperation of the natural environment. Various kinds of wild fruits have shown numerous bioactivities, such as antioxidant, antimicrobial, anti-inflammatory, anticancer, and anti-acetylcholinesterase activities. Some wild fruits have more than one bioactivity. For example, Aristotelia chilensis possesses anti-inflammatory, antiedema, and gastroprotective activities. The consumption and utilization of some wild fruits have been increasing, and some wild fruits have been developed into functional foods. In the future, for full utilization of wild fruit resources, more bioactivities of wild fruits should be evaluated, and bioactive components should be isolated and identified. The mechanisms of action should be explored further. In addition, the toxicological evaluation of some wild fruits is also necessary for safe human consumption.

Acknowledgments: This work was supported by the National Natural Science Foundation of China (No. 81372976), a Key Project of the Guangdong Provincial Science and Technology Program (No. 2014B020205002), and the Hundred-Talents Scheme of Sun Yat-Sen University.

Author Contributions: Ya Li, Sha Li, and Hua-Bin Li conceived this paper; Ya Li, Jiao-Jiao Zhang, Dong-Ping Xu, Tong Zhou, and Yue Zhou wrote this paper; and Sha Li and Hua-Bin Li revised the paper.

Conflicts of Interest: The authors declare no conflict of interest.

\section{References}

1. Baliga, M.S.; Pai, R.J.; Bhat, H.P.; Palatty, P.L.; Boloor, R. Chemistry and medicinal properties of the Bakul (Mimusops elengi Linn): A review. Food Res. Int. 2011, 44, 1823-1829. [CrossRef]

2. Deng, G.F.; Lin, X.; Xu, X.R.; Gao, L.; Xie, J.F.; Li, H.B. Antioxidant capacities and total phenolic contents of 56 vegetables. J. Funct. Foods 2013, 5, 260-266. [CrossRef]

3. Fu, L.; Xu, B.T.; Xu, X.R.; Qin, X.S.; Gan, R.Y.; Li, H.B. Antioxidant capacities and total phenolic contents of 56 wild fruits from South China. Molecules 2010, 15, 8602-8617. [CrossRef] [PubMed]

4. Xia, E.Q.; Deng, G.F.; Guo, Y.J.; Li, H.B. Biological activities of polyphenols from grapes. Int. J. Mol. Sci. 2010, 11, 622-646. [CrossRef] [PubMed]

5. Fu, L.; Xu, B.T.; Xu, X.R.; Gan, R.Y.; Zhang, Y.; Xia, E.Q.; Li, H.B. Antioxidant capacities and total phenolic contents of 62 fruits. Food Chem. 2011, 129, 345-350. [CrossRef]

6. Deng, G.F.; Shen, C.; Xu, X.R.; Kuang, R.D.; Guo, Y.J.; Zeng, L.S.; Gao, L.L.; Lin, X.; Xie, J.F.; Xia, E.Q. Potential of fruit wastes as natural resources of bioactive compounds. Int. J. Mol. Sci. 2012, 13, 8308-8323. [CrossRef] [PubMed]

7. Li, A.N.; Li, S.; Zhang, Y.J.; Xu, X.R.; Chen, Y.M.; Li, H.B. Resources and biological activities of natural polyphenols. Nutrients 2014, 6, 6020-6047. [CrossRef] [PubMed]

8. Giampieri, F.; Alvarez-Suarez, J.M.; Battino, M. Strawberry and human health: Effects beyond antioxidant activity. J. Agric. Food Chem. 2014, 62, 3867-3876. [CrossRef] [PubMed]

9. Hoffmann, G.; Schwingshackl, L. Mediterranean diet supplemented with extra virgin olive oil reduces the incidence of invasive breast cancer in a randomised controlled trial. Evid. Based Med. 2016, 21, 72. [CrossRef] [PubMed]

10. Lobo, V.; Patil, A.; Phatak, A.; Chandra, N. Free radicals, antioxidants and functional foods: Impact on human health. Pharmacogn. Rev. 2010, 4, 118-126. [CrossRef] [PubMed]

11. Forbes-Hernandez, T.Y.; Giampieri, F.; Gasparrini, M.; Mazzoni, L.; Quiles, J.L.; Alvarez-Suarez, J.M.; Battino, M. The effects of bioactive compounds from plant foods on mitochondrial function: A focus on apoptotic mechanisms. Food Chem. Toxicol. 2014, 68, 154-182. [CrossRef] [PubMed]

12. Huang, W.J.; Zhang, X.; Chen, W.W. Role of oxidative stress in Alzheimer's disease (Review). Biomed. Rep. 2016, 4, 519-522. [CrossRef] [PubMed]

13. Halliwell, B.; Gutteridge, J.M.C. Free Radicals in Biology and Medicine, 3rd ed.; Oxford University Press: New York, NY, USA, 1999; pp. 331-332. 
14. Lock, K.; Pamerleau, J.; Causer, L.; Altmann, D.R.; McKee, M. The global burden of disease attributable to low consumption of fruit and vegetables: Implications for the global strategy on diet. Bull. World Health Organ. 2005, 83, 100-108. [PubMed]

15. Gescher, A.; Pastorino, U.; Plummer, S.M.; Manson, M.M. Suppression of tumor development by substances derived from the diet-mechanisms and clinical implications. Br. J. Clin. Pharmacol. 1998, 45, 1-12. [CrossRef] [PubMed]

16. Ansari, K.N. The free radicals-The hidden culprits: An update. Indian J. Med. Sci. 1997, 51, 319-336. [PubMed]

17. Halliwell, B.; Gutteridge, J.M.C. Role of free radicals and catalytic metal ions in human disease: An overview. Method Enzymol. 1990, 186, 1-85.

18. Li, A.N.; Li, S.; Li, H.B.; Xu, D.P.; Xu, X.R.; Chen, F. Total phenolic contents and antioxidant capacities of 51 edible and wild flowers. J. Funct. Foods 2014, 6, 319-330. [CrossRef]

19. Li, S.; Li, S.K.; Gan, R.Y.; Song, F.L.; Kuang, L.; Li, H.B. Antioxidant capacities and total phenolic contents of infusions from 223 medicinal plants. Ind. Crop Prod. 2013, 51, 289-298. [CrossRef]

20. Deng, G.F.; Xu, X.R.; Guo, Y.J.; Xia, E.Q.; Li, S.; Wu, S.; Chen, F.; Ling, W.H.; Li, H.B. Determination of antioxidant property and their lipophilic and hydrophilic phenolic contents in cereal grains. J. Funct. Foods 2012, 4, 906-914. [CrossRef]

21. Fu, L.; Xu, B.T.; Gan, R.Y.; Zhang, Y.; Xu, X.R.; Xia, E.Q.; Li, H.B. Total phenolic contents and antioxidant capacities of herbal and tea infusions. Int. J. Mol. Sci. 2011, 12, 2112-2124. [CrossRef] [PubMed]

22. Song, F.L.; Gan, R.Y.; Zhang, Y.; Xiao, Q.; Kuang, L.; Li, H.B. Total phenolic contents and antioxidant capacities of selected Chinese medicinal plants. Int. J. Mol. Sci. 2010, 11, 2362-2372. [CrossRef] [PubMed]

23. Alezandro, M.R.; Granato, D.; Genovese, M.I. Jaboticaba (Myrciaria jaboticaba (Vell.) Berg), a Brazilian grape-like fruit, improves plasma lipid profile in streptozotocin-mediated oxidative stress in diabetic rats. Food Res. Int. 2013, 54, 650-659. [CrossRef]

24. Margraf, T.; Santos, E.N.T.; de Andrade, E.F.; van Ruth, S.M.; Granato, D. Effects of geographical origin, variety and farming system on the chemical markers and in vitro antioxidant capacity of Brazilian purple grape juices. Food Res. Int. 2016, 82, 145-155. [CrossRef]

25. Macedo, L.F.L.; Rogero, M.M.; Guimaraes, J.P.; Granato, D.; Lobato, L.P.; Castro, I.A. Effect of red wines with different in vitro antioxidant activity on oxidative stress of high-fat diet rats. Food Chem. 2013, 137, 122-129. [CrossRef] [PubMed]

26. Granato, D.; Karnopp, A.R.; van Ruth, S.M. Characterization and comparison of phenolic composition, antioxidant capacity and instrumental taste profile of juices from different botanical origins. J. Sci. Food Agric. 2015, 95, 1997-2006. [CrossRef] [PubMed]

27. Blando, F.; Albano, C.; Liu, Y.Z.; Nicoletti, I.; Corradini, D.; Tommasi, N.; Gerardi, C.; Mita, G.; Kitts, D.D. Polyphenolic composition and antioxidant activity of the under-utilised Prunus mahaleb L. fruit. J. Sci. Food Agric. 2016, 96, 2641-2649. [CrossRef] [PubMed]

28. Ramos, A.S.; Souza, R.O.S.; Boleti, A.P.D.A.; Bruginski, E.R.D.; Lima, E.S.; Campos, F.R.; Machado, M.B. Chemical characterization and antioxidant capacity of the araca-pera (Psidium acutangulum): An exotic Amazon fruit. Food Res. Int. 2015, 75, 315-327. [CrossRef]

29. Hasbal, G.; Yilmaz-Ozden, T.; Can, A. Antioxidant and antiacetylcholinesterase activities of Sorbus torminalis (L.) Crantz (wild service tree) fruits. J. Food Drug Anal. 2015, 23, 57-62. [CrossRef]

30. Cardozo, M.L.; Ordonez, R.M.; Alberto, M.R.; Zampini, I.C.; Isla, M.I. Antioxidant and anti-inflammatory activity characterization and genotoxicity evaluation of Ziziphus mistol ripe berries, exotic Argentinean fruit. Food Res. Int. 2011, 44, 2063-2071. [CrossRef]

31. Barreca, D.; Lagana, G.; Ficarra, S.; Tellone, E.; Leuzzi, U.; Galtieri, A.; Bellocco, E. Evaluation of the antioxidant and cytoprotective properties of the exotic fruit Annona cherimola Mill. (Annonaceae). Food Res. Int. 2011, 44, 2302-2310. [CrossRef]

32. Rawat, S.; Jugran, A.; Giri, L.; Bhatt, I.D.; Rawal, R.S. Assessment of antioxidant properties in fruits of Myrica esculenta: A popular wild edible species in Indian Himalayan Region. Evid. Based Complement. Altern. 2011, 2011, 1-8. [CrossRef] [PubMed]

33. Garzon, G.A.; Narvaez, C.E.; Riedl, K.M.; Schwartz, S.J. Chemical composition, anthocyanins, non-anthocyanin phenolics and antioxidant activity of wild bilberry (Vaccinium meridionale Swartz) from Colombia. Food Chem. 2010, 122, 980-986. [CrossRef] 
34. Zheng, J.; Ding, C.; Wang, L.; Li, G.; Shi, J.; Li, H.; Wang, H.; Suo, Y. Anthocyanins composition and antioxidant activity of wild Lycium ruthenicum Murr. from Qinghai-Tibet Plateau. Food Chem. 2011, 126, 859-865. [CrossRef]

35. Mezadri, T.; Villano, D.; Fernandez-Pachon, M.S.; Garcia-Parrilla, M.C.; Troncoso, A.M. Antioxidant compounds and antioxidant activity in acerola (Malpighia emarginata DC.) fruits and derivatives. J. Food Compos. Anal. 2008, 21, 282-290. [CrossRef]

36. Koca, I.; Ustun, N.S.; Koca, A.F.; Karadeniz, B. Chemical composition, antioxidant activity and anthocyanin profiles of purple mulberry (Morus rubra) fruits. J. Food Agric. Environ. 2008, 6, 39-42.

37. Chizzola, R.; Saeidnejad, A.H.; Azizi, M.; Oroojalian, F.; Mardani, H. Bunium persicum: Variability in essential oil and antioxidants activity of fruits from different Iranian wild populations. Genet. Resour. Crop Evol. 2014, 61, 1621-1631. [CrossRef]

38. Panja, S.; Chaudhuri, D.; Ghate, N.B.; Minh, H.L.; Mandal, N. In vitro assessment of phytochemicals, antioxidant and DNA protective potential of wild edible fruit of Elaeagnus latifolia Linn. Fruits 2014, 69, 303-314. [CrossRef]

39. Ma, C.H.; Dastmalchi, K.; Whitaker, B.D.; Kennelly, E.J. Two new antioxidant malonated caffeoylquinic acid isomers in fruits of wild eggplant relatives. J. Agric. Food Chem. 2011, 59, 9645-9651. [CrossRef] [PubMed]

40. Barros, L.; Carvalho, A.M.; Ferreira, I.C.F.R. Exotic fruits as a source of important phytochemicals: Improving the traditional use of Rosa canina fruits in Portugal. Food Res. Int. 2011, 44, 2233-2236. [CrossRef]

41. Nabavi, S.F.; Nabavi, S.M.; Ebrahimzadeh, M.A.; Asgarirad, H. The antioxidant activity of wild medlar (Mespilus germanica L.) fruit, stem bark and leaf. Afr. J. Biotechnol. 2011, 10, 283-289.

42. Cespedes, C.L.; Valdez-Morales, M.; Avila, J.G.; El-Hafidi, M.; Alarcon, J.; Paredes-Lopez, O. Phytochemical profile and the antioxidant activity of Chilean wild black-berry fruits, Aristotelia chilensis (Mol) Stuntz (Elaeocarpaceae). Food Chem. 2010, 119, 886-895. [CrossRef]

43. Serce, S.; Ercisli, S.; Sengul, M.; Gunduz, K.; Orhan, E. Antioxidant activities and fatty acid composition of wild grown myrtle (Myrtus communis L.) fruits. Pharmacogn. Mag. 2010, 6, 9-12. [CrossRef] [PubMed]

44. Fu, Y.; Zhou, X.Z.; Chen, S.G.; Sun, Y.J.; Shen, Y.; Ye, X.Q. Chemical composition and antioxidant activity of Chinese wild raspberry (Rubus hirsutus Thunb.). LWT Food Sci. Technol. 2015, 60, 1262-1268. [CrossRef]

45. Woguem, V.; Maggi, F.; Fogang, H.P.D.; Tapondjou, L.A.; Womeni, H.M.; Quassinti, L.; Bramucci, M.; Vitali, L.A.; Petrelli, D.; Lupidi, G.; et al. Antioxidant, antiproliferative and antimicrobial activities of the volatile oil from the wild Pepper Piper capense used in Cameroon as a culinary spice. Nat. Prod. Commun. 2013, 8, 1791-1796. [PubMed]

46. Choi, J.Y.; Lee, S.J.; Lee, S.J.; Park, S.; Lee, J.H.; Shim, J.H.; El-Aty, A.M.A.; Jin, J.S.; Jeong, E.D.; Lee, W.S.; et al. Analysis and tentative structure elucidation of new anthocyanins in fruit peel of Vitis coignetiae Pulliat (meoru) using LC-MS/MS: Contribution to the overall antioxidant activity. J. Sep. Sci. 2010, 33, 1192-1197. [PubMed]

47. Fraternale, D.; Giamperi, L.; Bucchini, A.; Ricci, D. Antioxidant activity of Prunus spinosa L. fruit juice. Ital. J. Food Sci. 2009, 21, 337-346.

48. Banerjee, A.; Dasgupta, N.; De, B. In vitro study of antioxidant activity of Syzygium cumini fruit. Food Chem. 2005, 90, 727-733. [CrossRef]

49. Koh, K.; Kim, H.; Hang, S.; Park, Y.; Lee, C. Polyphenolic compounds and superoxide radical scavenging activity of Moru-Ju. Food Sci. Biotechnol. 2003, 12, 290-297.

50. Zhang, Y.M.; Sun, Y.J.; Xi, W.P.; Shen, Y.; Qiao, L.P.; Zhong, L.Z.; Ye, X.Q.; Zhou, Z.Q. Phenolic compositions and antioxidant capacities of Chinese wild mandarin (Citrus reticulata Blanco) fruits. Food Chem. 2014, 145, 674-680. [CrossRef] [PubMed]

51. Li, N.; Shi, J.L.; Wang, K. Profile and antioxidant activity of phenolic extracts from 10 crabapples (Malus Wild Species). J. Agric. Food Chem. 2014, 62, 574-581. [CrossRef] [PubMed]

52. Du, H.; Wu, J.; Li, H.; Zhong, P.X.; Xu, Y.J.; Li, C.H.; Ji, K.X.; Wang, L.S. Polyphenols and triterpenes from Chaenomeles fruits: Chemical analysis and antioxidant activities assessment. Food Chem. 2013, 141, 4260-4268. [CrossRef] [PubMed]

53. Braga, P.C.; Antonacci, R.; Wang, Y.Y.; Lattuada, N.; dal Sasso, M.; Marabini, L.; Fibiani, M.; lo Scalzo, R. Comparative antioxidant activity of cultivated and wild Vaccinium species investigated by EPR, human neutrophil burst and COMET assay. Eur. Rev. Med. Pharmacol. Sci. 2013, 17, 1987-1999. [PubMed] 
54. Akhbari, M.; Batooli, H.; Mozdianfard, M. Comparative study of composition and biological activities of SDE prepared essential oils from flowers and fruits of two Hypericum species from central Iran. Nat. Prod. Res. 2012, 26, 193-202. [CrossRef] [PubMed]

55. Ozgen, M.; Serce, S.; Gunduz, K.; Yen, F.; Kafkas, E.; Paydas, S. Determining total phenolics and antioxidant activity of selected Fragaria genotypes. Asian J. Chem. 2007, 19, 5573-5581.

56. Sasipriya, G.; Maria, C.L.; Siddhuraju, P. Influence of pressure cooking on antioxidant activity of wild (Ensete superbum) and commercial banana (Musa paradisiaca var. Monthan) unripe fruit and flower. J. Food Sci. Technol. Technol. 2014, 51, 2517-2525. [CrossRef] [PubMed]

57. Yildiz, H.; Ercisli, S.; Hegedus, A.; Akbulut, M.; Topdas, E.F.; Aliman, J. Bioactive content and antioxidant characteristics of wild (Fragaria vesca L.) and cultivated strawberry (Fragaria ananassa Duch.) fruits from Turkey. J. Appl. Bot. Food. Qual. 2014, 87, 274-278.

58. Dyduch-Sieminska, M.; Najda, A.; Dyduch, J.; Gantner, M.; Klimek, K. The content of secondary metabolites and antioxidant activity of wild strawberry fruit (Fragaria vesca L.). J. Anal. Methods Chem. 2015, 2015, 1-8. [CrossRef] [PubMed]

59. Mitic, M.N.; Kostic, D.A.; Pavlovic, A.N.; Dimitrijevic, D.S.; Veljkovic, J.N. Effects of solvent extraction system on concentration and antioxidant activity of strawberry phenolics. Agro FOOD Ind. Hi Tech 2014, 25, $24-28$.

60. Lee, H.H.; Moon, Y.S.; Yun, H.K.; Park, P.J.; Kwak, E.J. Contents of bioactive constituents and antioxidant activities of cultivated and wild raspberries. Korean J. Hortic. Sci. Technol. 2014, 32, 115-122. [CrossRef]

61. Pu, F.; Ren, X.L.; Zhang, X.P. Phenolic compounds and antioxidant activity in fruits of six Diospyros kaki genotypes. Eur. Food Res. Technol. 2013, 237, 923-932. [CrossRef]

62. Roman, L.; Stanila, A.; Stanila, S. Bioactive compounds and antioxidant activity of Rosa canina L. biotypes from spontaneous flora of Transylvania. Chem. Cent. J. 2013, 7, 73. [CrossRef] [PubMed]

63. Lu, Y.L.; Liu, Y.H.; Liang, W.L.; Chyuan, J.H.; Cheng, K.T.; Liang, W.L.; Hou, W.C. Antioxidant activities of different wild bitter gourd (Momordica charantia L. var. abbreviata Seringe) cultivars. Bot. Stud. 2012, 53, 207-214.

64. Esfahlan, A.; Jamei, R. Properties of biological activity of ten wild almond (Prunus amygdalus L.) species. Turk. J. Biol. 2012, 36, 201-209.

65. Bunea, A.; Rugina, D.O.; Pintea, A.M.; Sconta, Z.; Bunea, C.I.; Socaciu, C. Comparative polyphenolic content and antioxidant activities of some wild and cultivated blueberries from Romania. Not. Bot. Horti Agrobot. Cluj-Napoca 2011, 39, 70-76.

66. Ghafar, M.F.A.; Prasad, K.N.; Weng, K.K.; Ismail, A. Flavonoid, hesperidine, total phenolic contents and antioxidant activities from Citrus species. Afr. J. Biotechnol. 2010, 9, 326-330.

67. Isfahlan, A.J.; Mahmoodzadeh, A.; Hassanzadeh, A.; Heidari, R.; Jamei, R. Antioxidant and antiradical activities of phenolic extracts from Iranian almond (Prunus amygdalus L.) hulls and shells. Turk. J. Biol. 2010, 34, 165-173.

68. Giovanelli, G.; Buratti, S. Comparison of polyphenolic composition and antioxidant activity of wild Italian blueberries and some cultivated varieties. Food Chem. 2009, 112, 903-908. [CrossRef]

69. Kubota, M.; Ishikawa, C.; Sugiyama, Y.; Fukumoto, S.; Miyagi, T.; Kumazawa, S. Anthocyanins from the fruits of Rubus croceacanthus and Rubus sieboldii, wild berry plants from Okinawa, Japan. J. Food Compos. Anal. 2012, 28, 179-182. [CrossRef]

70. Mazur, B.; Borowska, E.J.; Polak, M. Content of vitamin C in and antioxidant capacity of wild and cultivated cranberry fruit and of their pulps. Zywnosc Nauka Technol. Jakosc 2009, 16, 130-137.

71. Vollmannova, A.; Musilova, J.; Toth, T.; Arvay, J.; Bystricka, J.; Medvecky, M.; Daniel, J. Phenolic compounds, antioxidant activity and $\mathrm{Cu}, \mathrm{Zn}, \mathrm{Cd}$ and $\mathrm{Pb}$ content in wild and cultivated cranberries and blueberries. Int. J. Environ. Anal. Chem. 2014, 94, 1445-1451. [CrossRef]

72. Augusto, T.R.; Salinas, E.S.S.; Alencar, S.M.; D'Arce, M.A.B.R.; Camargo, A.C.D.; Vieira, T.M.F.D. Phenolic compounds and antioxidant activity of hydroalcoholic extracts of wild and cultivated murtilla (Ugni molinae Turcz.). Food Sci. Technol. 2014, 34, 667-679. [CrossRef]

73. Netzel, M.; Netzel, G.; Tian, Q.G.; Schwartz, S.; Konczak, I. Native Australian fruits - a novel source of antioxidants for food. Innov. Food Sci. Emerg. Technol. 2007, 8, 339-346. [CrossRef] 
74. Lamien-Meda, A.; Lamien, C.E.; Compaore, M.M.Y.; Meda, R.N.T.; Kiendrebeogo, M.; Zeba, B.; Millogo, J.F.; Nacoulma, O.G. Polyphenol content and antioxidant activity of fourteen wild edible fruits from Burkina Faso. Molecules 2008, 13, 581-594. [CrossRef] [PubMed]

75. Fazio, A.; Plastina, P.; Meijerink, J.; Witkamp, R.W.; Gabriele, B. Comparative analyses of seeds of wild fruits of Rubus and Sambucus species from Southern Italy: Fatty acid composition of the oil, total phenolic content, antioxidant and anti-inflammatory properties of the methanolic extracts. Food Chem. 2013, 140, 817-824. [CrossRef] [PubMed]

76. Malta, L.G.; Tessaro, E.P.; Eberlin, M.; Pastore, G.M.; Liu, R.H. Assessment of antioxidant and antiproliferative activities and the identification of phenolic compounds of exotic Brazilian fruits. Food Res. Int. 2013, 53, 417-425. [CrossRef]

77. Omena, C.M.B.; Valentim, I.B.; Guedes, G.D.; Rabelo, L.A.; Mano, C.M.; Bechara, E.J.H.; Sawaya, A.C.H.F.; Trevisan, M.T.S.; da Costa, J.G.; Ferreira, R.C.S. Antioxidant, anti-acetylcholinesterase and cytotoxic activities of ethanol extracts of peel, pulp and seeds of exotic Brazilian fruits. Food Res. Int. 2012, 49, 334-344. [CrossRef]

78. Santacruz, L.; Carriazo, J.G.; Almanza, O.; Osorio, C. Anthocyanin composition of wild Colombian fruits and antioxidant capacity measurement by electron paramagnetic resonance spectroscopy. J. Agric. Food Chem. 2012, 60, 1397-1404. [CrossRef] [PubMed]

79. Almeida, M.M.B.; de Sousa, P.H.M.; Arriaga, A.M.C.; do Prado, G.M.; Magalhaes, C.E.D.C.; Maia, G.A.; de Lemos, T.L.G. Bioactive compounds and antioxidant activity of fresh exotic fruits from northeastern Brazil. Food Res. Int. 2011, 44, 2155-2159. [CrossRef]

80. Chalise, J.P.; Acharya, K.; Gurung, N.; Bhusal, R.P.; Gurung, R.; Skalko-Basnet, N.; Basnet, P. Antioxidant activity and polyphenol content in edible wild fruits from Nepal. Int. J. Food Sci. Nutr. 2010, 61, 425-432. [CrossRef] [PubMed]

81. Ndhlala, A.R.; Mupure, C.H.; Chitindingu, K.; Benhura, M.A.; Muchuweti, M. Antioxidant potentials and degrees of polymerization of six wild fruits. Sci. Res. Essays 2006, 1, 87-92.

82. Genovese, M.I.; Pinto, M.D.S.; Goncalves, A.E.D.S.; Lajolo, F.M. Bioactive compounds and antioxidant capacity of exotic fruits and commercial frozen pulps from Brazil. Food Sci. Technol. Int. 2008, 14, 207-214. [CrossRef]

83. Oszmianski, J.; Nowicka, P.; Teleszko, M.; Wojdylo, A.; Cebulak, T.; Oklejewicz, K. Analysis of phenolic compounds and antioxidant activity in wild blackberry fruits. Int. J. Mol. Sci. 2015, 16, 14540-14553. [CrossRef] [PubMed]

84. Sharma, P.B.; Handique, P.J.; Devi, H.S. Antioxidant properties, physico-chemical characteristics and proximate composition of five wild fruits of Manipur, India. J. Food Sci. Technol. 2015, 52, 894-902. [CrossRef] [PubMed]

85. Ruiz-Rodriguez, B.M.; Sanchez-Moreno, C.; de Ancos, B.; Sanchez-Mata, M.D.; Fernandez-Ruiz, V.; Camara, M.; Tardio, J. Wild Arbutus unedo L. and Rubus ulmifolius Schott fruits are underutilized sources of valuable bioactive compounds with antioxidant capacity. Fruits 2014, 69, 435-448. [CrossRef]

86. Ruiz-Rodriguez, B.M.; de Ancos, B.; Sanchez-Moreno, C.; Fernandez-Ruiz, V.; Sanchez-Mata, M.D.; Camara, M.; Tardio, J. Wild blackthorn (Prunus spinosa L.) and hawthorn (Crataegus monogyna Jacq.) fruits as valuable sources of antioxidants. Fruits 2014, 69, 61-73. [CrossRef]

87. Rufino, M.S.M.; Alves, R.E.; Fernandes, F.A.N.; Brito, E.S. Free radical scavenging behavior of ten exotic tropical fruits extracts. Food Res. Int. 2011, 44, 2072-2075. [CrossRef]

88. Egea, I.; Sanchez-Bel, P.; Romojaro, F.; Pretel, M.T. Six edible wild fruits as potential antioxidant additives or nutritional supplements. Plant Food Hum. Nutr. 2010, 65, 121-129. [CrossRef] [PubMed]

89. Ndhlala, A.R.; Chitindingu, K.; Mupure, C.; Murenje, T.; Ndhlala, F.; Benhura, M.A.; Muchuweti, M. Antioxidant properties of methanolic extracts from Diospyros mespiliformis (jackal berry), Flacourtia indica (Batoka plum), Uapaca kirkiana (wild loquat) and Ziziphus mauritiana (yellow berry) fruits. Int. J. Food Sci. Technol. 2008, 43, 284-288. [CrossRef]

90. Saklani, S.; Badhani, A.; Mishra, A.P.; Chandra, S. Health promoting phytochemicals their concentration and antioxidant activity of wild edible fruits of Uttarakhand, India. Asian. J. Chem. 2012, 24, 5558-5560. 
91. Dembitsky, V.M.; Poovarodom, S.; Leontowicz, H.; Leontowicz, M.; Vearasilp, S.; Trakhtenberg, S.; Gorinstein, S. The multiple nutrition properties of some exotic fruits: Biological activity and active metabolites. Food Res. Int. 2011, 44, 1671-1701. [CrossRef]

92. Contreras-Calderon, J.; Calderon-Jaimes, L.; Guerra-Hernandez, E.; Garcia-Villanova, B. Antioxidant capacity, phenolic content and vitamin C in pulp, peel and seed from 24 exotic fruits from Colombia. Food Res. Int. 2011, 44, 2047-2053. [CrossRef]

93. De Assis, S.; Vellosa, J.C.R.; Brunetti, I.L.; Khalil, N.M.; Leite, K.M.D.C.; Martins, A.B.G.; Oliveira, O.M.M.D. Antioxidant activity, ascorbic acid and total phenol of exotic fruits occurring in Brazil. Int. J. Food Sci. Nutr. 2009, 60, 439-448. [CrossRef] [PubMed]

94. Ribeiro, A.B.; Bonafe, E.G.; Silva, B.C.; Montanher, P.F.; Santos Junior, O.O.; Boeing, J.S.; Visentainer, J.V. Antioxidant capacity, total phenolic content, fatty acids and correlation by principal component analysis of exotic and native fruits from Brazil. J. Braz. Chem. Soc. 2013, 24, 797-804. [CrossRef]

95. Luximon-Ramma, A.; Bahorun, T.; Crozier, A. Antioxidant actions and phenolic and vitamin C contents of common Mauritian exotic fruits. J. Sci. Food Agric. 2003, 83, 496-502. [CrossRef]

96. Radovanovic, B.C.; Andelkovic, A.S.M.; Radovanovic, A.B.; Andelkovic, M.Z. Antioxidant and antimicrobial activity of polyphenol extracts from wild berry fruits grown in Southeast Serbia. Trop. J. Pharm. Res. 2013, 12, 813-819. [CrossRef]

97. Leontowicz, H.; Leontowicz, M.; Drzewiecki, J.; Haruenkit, R.; Poovarodom, S.; Park, Y.S.; Jung, S.T.; Kang, S.G.; Trakhtenberg, S.; Gorinstein, S. Bioactive properties of snake fruit (Salacca edulis Reinw) and mangosteen (Garcinia mangostana) and their influence on plasma lipid profile and antioxidant activity in rats fed cholesterol. Eur. Food Res. Technol. 2006, 223, 697-703. [CrossRef]

98. Papandreou, M.A.; Dimakopoulou, A.; Linardaki, Z.I.; Cordopatis, P.; Klimis-Zacas, D.; Margarity, M.; Lamari, F.N. Effect of a polyphenol-rich wild blueberry extract on cognitive performance of mice, brain antioxidant markers and acetylcholinesterase activity. Behav. Brain Res. 2009, 198, 352-358. [CrossRef] [PubMed]

99. Gorinstein, S.; Poovarodom, S.; Leontowicz, H.; Leontowicz, M.; Namiesnik, J.; Vearasilp, S.; Haruenkit, R.; Ruamsuke, P.; Katrich, E.; Tashma, Z. Antioxidant properties and bioactive constituents of some rare exotic Thai fruits and comparison with conventional fruits in vitro and in vivo studies. Food Res. Int. 2011, 44, 2222-2232. [CrossRef]

100. Cilerdzic, J.; Vukojevc, J.; Stajic, M.; Stanojkovic, T.; Glamoclija, J. Biological activity of Ganoderma lucidum basidiocarps cultivated on alternative and commercial substrate. J. Ethnopharmacol. 2014, 155, 312-319. [CrossRef] [PubMed]

101. Garcia, M.E.; Blanco, J.L. Mycosis in domestic animals. Rev. Iberoam. Micol. 2000, 17, 2-7.

102. Mariem, C.; Sameh, M.; Nadhem, S.; Soumaya, Z.; Najiba, Z.; Raoudha, E.G. Antioxidant and antimicrobial properties of the extracts from Nitraria retusa fruits and their applications to meat product preservation. Ind. Crops Prod. 2014, 55, 295-303. [CrossRef]

103. Belkhir, M.; Rebai, O.; Dhaouadi, K.; Congiu, F.; Tuberoso, C.; Amri, M.; Fattouch, S. Comparative analysis of Tunisian wild Crataegus azarolus (Yellow Azarole) and Crataegus monogyna (Red Azarole) leaf, fruit, and traditionally derived syrup: Phenolic profiles and antioxidant and antimicrobial activities of the aqueous-acetone extracts. J. Agric. Food Chem. 2013, 61, 9594-9601. [CrossRef] [PubMed]

104. Ozcelik, B.; Koca, U.; Kaya, D.; Sekeroglu, N. Evaluation of the in vitro bioactivities of mahaleb cherry (Prunus mahaleb L.). Romanian Biotech. Lett. 2012, 17, 7863-7872.

105. Kyung, K.H.; Woo, Y.H.; Kim, D.S.; Park, H.J.; Kim, Y.S. Antimicrobial activity of an edible wild plant, apiifolia Virgin's Bower (Clematis apiifolia DC). Food Sci. Biotechnol. 2007, 16, 1051-1054.

106. Panlilio, B.G.; Franzblau, S.; Aguinaldo, A.M. Variability of the antitubercular activity of Ampalaya (Momordica charantia L.) from selected provinces in Luzon, Philippines. Philipp. Agric. Sci. 2007, 90, 337-340.

107. Besbes, M.; Omri, A.; Cheraif, I.; Daami, M.; Ben Jannet, H.; Mastouri, M.; Aouni, M.; Selmi, B. Chemical composition and antimicrobial activity of essential oils from Scabiosa arenaria Forssk growing wild in Tunisia. Chem. Biodivers. 2012, 9, 829-839. [CrossRef] [PubMed]

108. Ahmed, D.; Waheed, A.; Chaudhary, M.A.; Khan, S.R.; Hannan, A.; Barkaat, M. Nutritional and antimicrobial studies on leaves and fruit of Carissa opaca Stapf ex Haines. Asian J. Chem. 2011, 23, 2072-2076. 
109. Hussain, A.; Qarshi, I.A.; Liaqat, R.; Akhtar, S.; Aziz, I.; Ullah, I.; Shinwari, Z.K. Antimicrobial potential of leaf and fruit extracts and oils of wild and cultivated edible olive. Pak. J. Bot. 2014, 46, 1463-1468.

110. Hassan, L.E.A.; Sirat, H.M.; Yagi, S.M.A.; Koko, W.S.; Abdelwahab, S.I. In vitro antimicrobial activities of chloroformic, hexane and ethanolic extracts of Citrullus lanatus var. citroides (wild melon). J. Med. Plants Res. 2011, 5, 1338-1344.

111. McCook-Russell, K.P.; Nair, M.G.; Facey, P.C.; Bowen-Forbes, C.S. Nutritional and nutraceutical comparison of Jamaican Psidium cattleianum (strawberry guava) and Psidium guajava (common guava) fruits. Food Chem. 2012, 134, 1069-1073. [CrossRef] [PubMed]

112. Cesoniene, L.; Jasutiene, I.; Sarkinas, A. Phenolics and anthocyanins in berries of European cranberry and their antimicrobial activity. Med. Lith. 2009, 45, 992-999.

113. Turker, A.U.; Yildirim, A.B.; Karakas, F.P. Antibacterial and antitumor activities of some wild fruits grown in Turkey. Biotechnol. Biotechnol. Equip. 2011, 26, 2765-2772. [CrossRef]

114. Pio-Leon, J.F.; Diaz-Camacho, S.P.; Lopez-Lopez, M.A.; Uribe-Beltran, M.D.; Willms, K.; Lopez-Angulo, G.; Montes-Avila, J.; Delgado-Vargas, F. Antibacterial activity of extracts obtained from the nanchi (Byrsonima crassifolia (L.) Kunth), arrayan (Psidium sartorianum (O. Berg) Nied.) and ayale (Crescentia alata Kunth) fruits. Bol. Latinoam. Caribe Plantas Med. 2013, 12, 356-364.

115. Adeola, A.A.; Adeola, O.O.; Dosumu, O.O. Comparative analyses of phytochemicals and antimicrobial properties of extracts of wild Tamarindus indica pulps. Afr. J. Microbiol. Res. 2010, 4, 2769-2779.

116. Lu, Y.L.; Liu, Y.H.; Liang, W.L.; Chuang, J.H.; Cheng, K.T.; Liang, H.J.; Hou, W.C. Antibacterial and cytotoxic activities of different wild bitter gourd cultivars (Momordica charantia L. var. abbreviata Seringe). Bot. Stud. 2011, 52, 427-434.

117. Boughalleb, N.; Trabelsi, L.; Harzallah-Skhiri, F. Antifungal activity from polar and non-polar extracts of some Chenopodiaceae wild species growing in Tunisia. Nat. Prod. Res. 2009, 23, 988-997. [CrossRef] [PubMed]

118. Knox, Y.M.; Suzutani, T.; Yosida, I.; Azuma, M. Anti-influenza virus activity of crude extract of Ribes nigrum L. Phytother. Res. 2003, 17, 120-122. [CrossRef] [PubMed]

119. Nikolaeva-Glomb, L.; Mukova, L.; Nikolova, N.; Badjakov, I.; Dincheva, I.; Kondakova, V.; Doumanova, L.; Galabov, A.S. In vitro antiviral activity of a series of wild berry fruit extracts against representatives of Picorna-, Orthomyxo- and Paramyxoviridae. Nat. Prod. Commun. 2014, 9, 51-54. [PubMed]

120. Cuevas-Rodriguez, E.O.; Dia, V.P.; Yousef, G.G.; Garcia-Saucedo, P.A.; Lopez-Medina, J.; Paredes-Lopez, O.; Gonzalez De Mejia, E.; Lila, M.A. Inhibition of pro-inflammatory responses and antioxidant capacity of Mexican blackberry (Rubus spp.) extracts. J. Agric. Food Chem. 2010, 58, 9542-9548. [CrossRef] [PubMed]

121. Stamler, J.S.; Single, D.; Loscalzo, J. Biochemistry of nitric oxide and its redox-activated forms. Science 1992, 258, 1892-1902. [CrossRef]

122. Varesio, L.; Battaglia, F.; Raggi, F.L.B.; Bosco, M.C. Macrophage inflammatory protein-3 $\alpha /$ CCL-20 is transcriptionally induced by the iron chelator desferrioxamine in human mononuclear phagocytes through nuclear factor (NF)-кB. Mol. Immunol. 2010, 47, 685-693. [CrossRef] [PubMed]

123. Bowen-Forbes, C.S.; Zhang, Y.; Nair, M.G. Anthocyanin content, antioxidant, anti-inflammatory and anticancer properties of blackberry and raspberry fruits. J. Food Compos. Anal. 2010, 23, 554-560. [CrossRef]

124. Bowen-Forbes, C.S.; Mulabagal, V.; Liu, Y.; Nair, M.G. Ursolic acid analogues: non-phenolic functional food components in Jamaican raspberry fruits. Food Chem. 2009, 116, 633-637. [CrossRef]

125. Grace, M.H.; Esposito, D.; Dunlap, K.L.; Lila, M.A. Comparative analysis of phenolic content and profile, antioxidant capacity, and anti-inflammatory bioactivity in wild Alaskan and commercial Vaccinium Berries. J. Agric. Food Chem. 2014, 62, 4007-4017. [CrossRef] [PubMed]

126. Karin, M.; Ben-Neriah, Y. Phosphorylation meets ubiquitination: The control of NF-kappa B activity. Annu. Rev. Immunol. 2000, 18, 621-663. [CrossRef] [PubMed]

127. Karin, M.; Yamamoto, Y.; Wang, Q.M. The IKK NF-kB system: A treasure trove for drug development. Nat. Rev. Drug Discov. 2004, 3, 17-26. [CrossRef] [PubMed]

128. Kang, J.; Thakali, K.M.; Jensen, G.S.; Wu, X.L. Phenolic acids of the two major blueberry species in the US market and their antioxidant and anti-inflammatory activities. Plant Food Hum. Nutr. 2015, 70, 56-62. [CrossRef] [PubMed] 
129. Hsu, C.; Tsai, T.H.; Li, Y.Y.; Wu, W.H.; Huang, C.J.; Tsai, P.J. Wild bitter melon (Momordica charantia Linn. var. abbreviata Ser.) extract and its bioactive components suppress Propionibacterium acnes-induced inflammation. Food Chem. 2012, 135, 976-984. [CrossRef] [PubMed]

130. Cespedes, C.L.; Alarcon, J.; Avila, J.; Nieto, A. Anti-inflammatory activity of Aristotelia chilensis Mol. (Stuntz) (Elaeocarpaceae). Bol. Latinoam. Caribe Plantas Med. 2010, 9, 127-135.

131. Cespedes, C.L.; Alarcon, J.; Avila, J.; El-Hafidi, M. Anti-inflammatory, antioedema and gastroprotective activities of Aristotelia chilensis extracts, Part 2. Bol. Latinoam. Caribe Plantas Med. 2010, 9, 432-439.

132. Do Nascimento, G.E.; Hamm, L.A.; Baggio, C.H.; Werner, M.F.D.; Iacomini, M.; Cordeiro, L.M.C. Structure of a galactoarabinoglucuronoxylan from tamarillo (Solanum betaceum), a tropical exotic fruit, and its biological activity. Food Chem. 2013, 141, 510-516. [CrossRef] [PubMed]

133. Chu, Y.F.; Sun, J.; Wu, X.Z.; Liu, R.H. Antioxidant and antiproliferative activities of common vegetables. J. Agric. Food Chem. 2002, 50, 6910-6916. [CrossRef]

134. Liu, R.H. Health benefits of fruits and vegetables are from additive and synergistic combinations of phytochemicals. Am. J. Clin. Nutr. 2003, 78, 517S-520S. [PubMed]

135. Li, F.; Li, S.; Li, H.B.; Deng, G.F.; Ling, W.H.; Wu, S.; Xu, X.R.; Chen, F. Antiproliferative activity of peels, pulps and seeds of 61 fruits. J. Funct. Foods 2013, 5, 1298-1309. [CrossRef]

136. Zhou, Y.; Li, Y.; Zhou, T.; Zheng, J.; Li, S.; Li, H.B. Dietary natural products for prevention and treatment of liver cancer. Nutrients 2016, 8, 156. [CrossRef] [PubMed]

137. Li, F.; Li, S.; Li, H.B.; Deng, G.F.; Ling, W.H.; Xu, X.R. Antiproliferative activities of tea and herbal infusions. Food Funct. 2013, 4, 530-538. [CrossRef] [PubMed]

138. Bagchi, D.; Swaroop, A.; Preuss, H.G.; Bagchi, M. Free radical scavenging, antioxidant and cancer chemoprevention by grape seed proanthocyanidin: An overview. Mutat. Res. Fundam. Mol. Mech. Mutagen. 2014, 768, 69-73. [CrossRef] [PubMed]

139. Schmidt, B.M.; Howell, A.B.; McEniry, B.; Knight, C.T.; Seigler, D.; Erdman, J.W.; Lila, M.A. Effective separation of potent antiproliferation and antiadhesion components from wild blueberry (Vaccinium angustifolium Ait.) fruits. J. Agric. Food Chem. 2004, 52, 6433-6442. [CrossRef] [PubMed]

140. Saini, R.; Dangwal, K.A.; Singh, H.; Garg, V. Antioxidant and antiproliferative activities of phenolics isolated from fruits of Himalayan yellow raspberry (Rubus ellipticus). J. Food Sci. Technol. 2014, 51, 3369-3375. [CrossRef] [PubMed]

141. Wang, S.Y.; Lewers, K.S.; Bowman, L.; Ding, M. Antioxidant activities and anticancer cell proliferation properties of wild strawberries. J. Am. Soc. Hortic. Sci. 2007, 132, 647-658.

142. Liu, X.C.; Liu, Q.; Chen, X.B.; Zhou, L.; Liu, Z.L. Larvicidal activity of the essential oil from Tetradium glabrifolium fruits and its constituents against Aedes albopictus. Pest Manag. Sci. 2015, 71, 1582-1586. [CrossRef] [PubMed]

143. Hassan, L.E.A.; Koko, W.S.; Osman, E.B.E.; Dahab, M.M.; Sirat, H.M. In vitro antigiardial activity of Citrullus lanatus Var. citroides extracts and cucurbitacins isolated compounds. J. Med. Plants Res. 2011, 5, 3338-3346.

144. Wang, C.F.; Yang, K.; Zhang, H.M.; Cao, J.; Fang, R.; Liu, Z.L.; Du, S.S.; Wang, Y.Y.; Deng, Z.W.; Zhou, L.G. Components and insecticidal activity against the Maize Weevils of Zanthoxylum schinifolium fruits and leaves. Molecules 2011, 16, 3077-3088. [CrossRef] [PubMed]

145. Fang, R.; Jiang, C.H.; Wang, X.Y.; Zhang, H.M.; Liu, Z.L.; Zhou, L.; Du, S.S.; Deng, Z.W. Insecticidal activity of essential oil of Carum Carvi fruits from China and its main components against two grain storage insects. Molecules 2010, 15, 9391-9402. [CrossRef] [PubMed]

146. Nde, C.; Njamen, D.; Mbanya, J.C.; Zierau, O.; Vollmer, G.; Fommn, Z.T. Estrogenic effects of a methanol extract of the fruit of Brenania brieyi de Wild (Rubiaceae). J. Nat. Med. 2007, 61, 86-89.

147. Harris, C.S.; Cuerrier, A.; Lamont, E.; Haddad, P.S.; Arnason, J.T.; Bennett, S.A.L.; Johns, T. Investigating wild berries as a dietary approach to reducing the formation of advanced glycation endproducts: Chemical correlates of in vitro antiglycation activity. Plant Food Hum. Nutr. 2014, 69, 71-77. [CrossRef] [PubMed]

148. Zhang, Y.; Zhang, Z.Y.; Yang, Y.N.; Zu, X.Y.; Guan, D.; Wang, Y.P. Diuretic activity of Rubus idaeus L. (Rosaceae) in rats. Trop. J. Pharm. Res. 2011, 10, 243-248. [CrossRef]

149. Skrovankova, S.; Sumczynski, D.; Mlcek, J.; Jurikova, T.; Sochor, J. Bioactive compounds and antioxidant activity in different types of berries. Int. J. Mol. Sci. 2015, 16, 24673-24706. [CrossRef] [PubMed] 
150. Namiesnik, J.; Vearasilp, K.; Nemirovski, A.; Leontowicz, H.; Leontowicz, M.; Pasko, P.; Martinez-Ayala, A.L.; Gonzalez-Aguilar, G.A.; Suhaj, M.; Gorinstein, S. In vitro studies on the relationship between the antioxidant activities of some berry extracts and their binding properties to serum albumin. Appl. Biochem. Biotechnol. 2014, 172, 2849-2865. [CrossRef] [PubMed]

151. De Souza, V.R.; Pereira, P.A.P.; da Silva, T.L.T.; Lima, L.C.D.; Pio, R.; Queiroz, F. Determination of the bioactive compounds, antioxidant activity and chemical composition of Brazilian blackberry, red raspberry, strawberry, blueberry and sweet cherry fruits. Food Chem. 2014, 156, 362-368. [CrossRef] [PubMed]

152. Yildiz, H.; Sengul, M.; Celik, F.; Hegedus, A.; Ercisli, S.; Tosun, M. Some phytochemical and antioxidant characteristics of wild and cultivated blackberry (Rubus caucasicus) fruits. J. Food Agric. Environ. 2010, 8, 156-159.

(C) 2016 by the authors; licensee MDPI, Basel, Switzerland. This article is an open access article distributed under the terms and conditions of the Creative Commons Attribution (CC-BY) license (http://creativecommons.org/licenses/by/4.0/). 